TITLE:

ASCIDIANS COLLECTED BY

MESSRS. RENZI WADA AND SEIZI

WADA FROM THE PEARL-OYSTER

BED IN THE ARAFURA SEA IN 1940

AUTHOR(S):

Tokioka, Takasi

CITATION:

Tokioka, Takasi. ASCIDIANS COLLECTED BY MESSRS. RENZI WADA AND SEIZI WADA FROM THE PEARL-OYSTER BED IN THE ARAFURA SEA IN 1940. PUBLICATIONS OF THE SETO MARINE BIOLOGICAL LABORATORY 1952, 2(2): 91-142

ISSUE DATE:

1952-10-05

URL:

http://hdl.handle.net/2433/174683

RIGHT: 


\title{
ASCIDIANS COLLECTED BY MESSRS. RENZI WADA AND SEIZI WADA FROM THE PEARL-OYSTER BED IN THE ARAFURA SEA IN 1940*
}

\author{
TAKASI TOKIOKA
}

Seto Marine Biological Laboratory, Sirahama

With 29 Text figures

The present material consists of 27 species collected by Mr. RenzI WADA of the former Nan'yô Pearl Company and Mr. SEizI WADA, an associate of the former Palao Tropical Biological Station, from the pearl-oyster bed off Melville in the Arafura Sea during the period from September to November of 1940. I express here my hearty thanks to Messrs. R. WADA and S. WADA for their kindness in offerring me the present precious material. I am also very grateful to Prof. T. Komal for his kind guidance and incessant encouragement. The present work is a part of the study progressed by the financial aid from the Ministry of Education.

\section{Didemum (Polysyncraton) arafurensis n. $\mathrm{sp}$.}

(Fig. 1)

Two colonies collected by Mr. R. WADA. One is $30 \mathrm{~mm}$ long $\times 10-15 \mathrm{~mm}$ wide in extent and $1 \mathrm{~mm}$ in thickness. The other is very small, only $5 \mathrm{~mm} \times$ $5 \mathrm{~mm}$ in extent and $1-1.5 \mathrm{~mm}$ in thickness. Test white and covered densely with spicules which are rather small, less than $70 \mu$, consisting of many rays pointed acutely, and distributed densely and evenly throughout the test. On the larger colony, spicules are rather sparse at the position where each zooid is situated. Cloacal aperture indistinct. Buds of the thorax and abdomen on the oesophagus.

Zooid: Colourless in the preserved state. Large zooids reach $1.2 \mathrm{~mm}$ in length, thorax as long as abdomen. Branchial aperture 6-lobed; atrial aperture a huge opening, extending from the dorsal ganglion to the anus and * Contributions from the Seto Marine Biological Laboratory, No. 180.

Publ. Seto. Mar. Biol. Lab., II (2), $1952 . \quad$ (Article 8) 
ventrally near the endostyle and provided with a short atrial languet ending in some zooids in two small lappets.
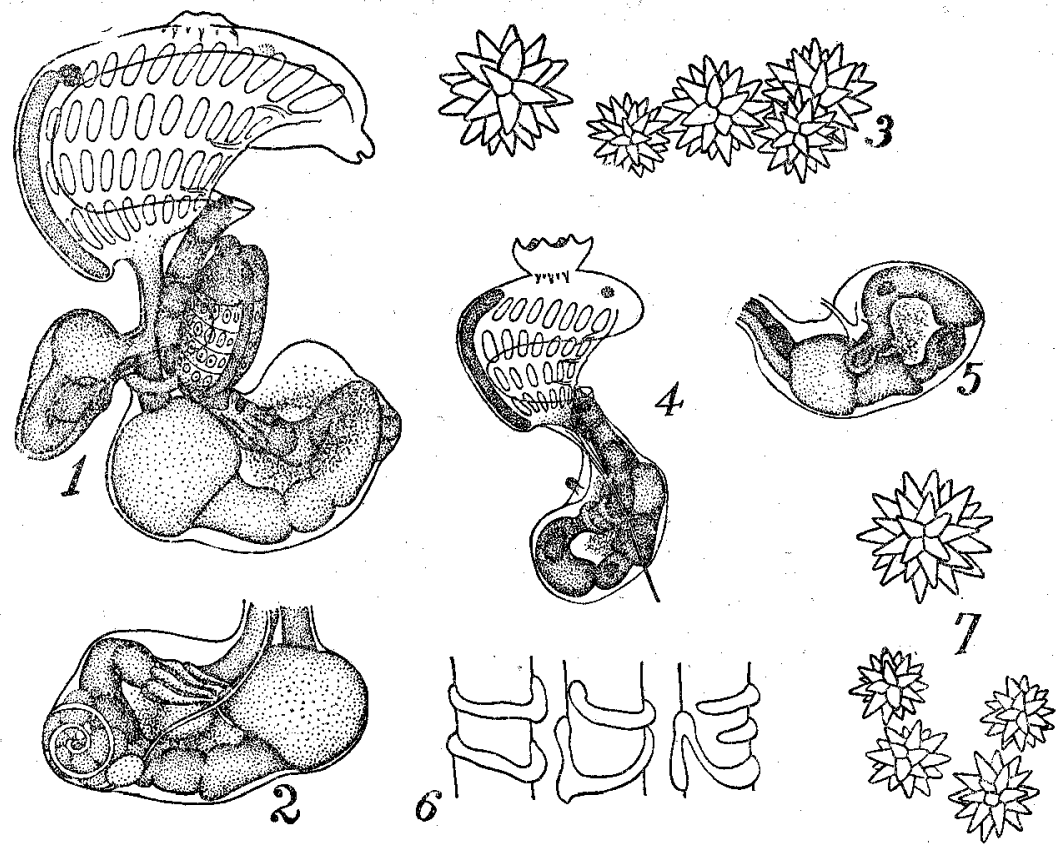

Fig. 1. Didemnum (Polysyncraton) arafurensis n. sp. 1-3 Large colony, 1Zooids $\times 45,7-$ Abdomen $\times 45,3-$ Spicules $\times 200,4-7$ Small colony, 4-Zooid $\times 45,5$-Abdomen $\times 45,6$-Circum-intestinal gland, 7-Spicules $\times 200$.

Thorax: Branchial sac with 4 stigmata-rows, each with 6-7 9-10 stigmata. Dorsal languet distinct. Tentacles 12,6 larger and 6 smaller. A thoracic organ, indicated by a small calcareous agglomerate, at the antero-ventral side of the atrial aperture on each side in some zooids of the larger colony.

Abdomen: Alimentary canal as in usual members of Didemnidae. Anus with two lobules. Testicular follicles up to 6 , vas deferens coils $2 \frac{1}{2}$ times in not fully mature state. Circumintestinal gland is consisting of several ingershaped blind sacs in zooids of the larger colony, while it is composed of two or three tubules surrounding the intestine in zooids of the smaller colony.

\section{Leptoclinides rufus (SLUTTER) 1909}

(Fig. 2)

Polysyncraton rufum; SiduTER (1909): Siboga-Exped., Monogr. LVI b, pp. 72-73, PI. IV fig. 5 . 
SLUITER (1914): Abhandl. Senckenberg. Naturforsch. Gesell., Bd. 45, Hft. 1, p. 77.

? Leptoclinides diemensis; MICHARLSEN (1924): Vid. Medd. fra Dansk nat. Foren., Bd. 77, pp. 331-336, Fig. 12 .

? Ieptoclinides lissus; HASTINGs (1931): Great Barrier Reef Exp., Vol. IV., No. 3, pp. 9394,Fig. 12 .

T. A colony found by Mr. R. WADA encrusting the shell of a pearl oyster. It is $70 \mathrm{~mm} \times 25-30 \mathrm{~mm}$ in extent and $1.5-2 \mathrm{~mm}$ in thickness. Test semitransparent and sparsely sprinkled with minute calcareous spicules which are smaller than $80 \mu$ and distributed rather evenly throughout the test, although they are slightly denser around the branchial apertures. The tip of each ray pointed very sharply. Zooids aggregated so as to form many small groups.

Zooids: Colourless in the preserved state, except ova which are somewhat yellowish. Large individuals reach $1.5-2.0 \mathrm{~mm}$ in length, abdomen slightly larger than thorax. Branchial aperture 6-lobed, atrial siphon short.

Thorax: About eight longitudinal muscular bands on each side of the thorax. Stigmata rows 4 , each consisting of ca. 9 stigmata. Tentacles 12,6 larger and 6 smaller. Dorsal languets of moderate size. Thoracic organ at each lateral side of the posterior part of the thorax. Each organ contains a calcareous aggregate in that structure. Anus bilobed and opening at the postero-dorsal corner of the thorax.

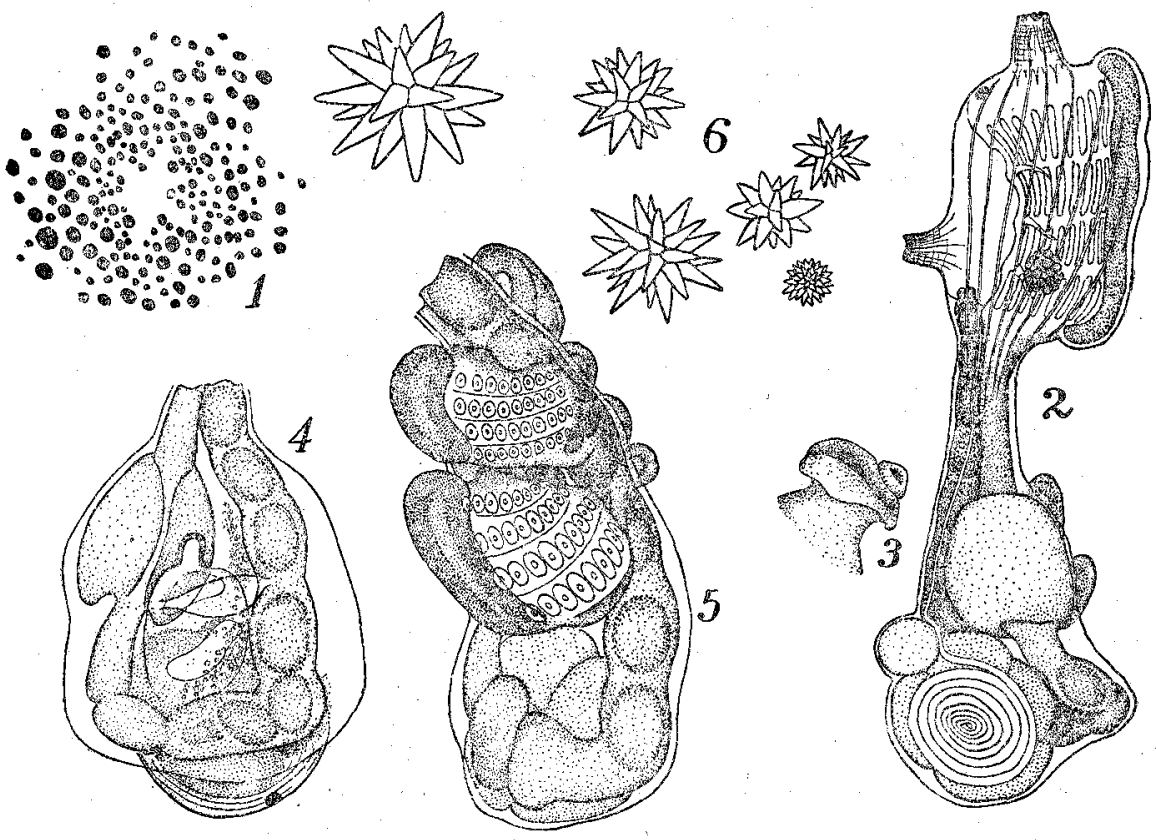

Fig. 2. Loptoclinides rufus (SLUITER). 1-A branchial aperture $\times 45,2-Z$ ooid $\times 45$, 3-Anus, 4-Abdomen $\times 75$, 5-Abdomen with buds $\times 75,6$-Spicules $\times 200$. 
Abdomen: Testicular follicles 4, vas deferens coils $8 \frac{1}{2} \sim 9 \frac{1}{2}$ times in mature state. Buds of thorax pyloric; usually two in number, although in some rare cases 4 small buds may be observed. Buds of abdomen oesophageal ? and usually several in number.

Remarks: Evidently the present specimen belongs to the group of $L$. dubius (Sluiter) and its allies. Among this group, Polysyncraton rufus Stuiter, $L$. diemensis MiCHAELSEN and $\mathcal{L}$. lissus HAstings resemble the present form most closely. The number of the testicular follicles in this specimen is nearest to that of $\mathcal{L}$. diemensis, but I prefer to adopt the oldest name of these three species, L. rufus, for the present specimen, since I can not discern any fundamental difference between these three species.

\section{Leptoclinides dubius (SLUITER) 1909}

(Fig. 3)

Polysyncraton dubium; SLurTer (1909): Siboga-Exped., Monogr. LVI b, pp. 69-71, Pl. IV, fig. 3, Pl. VII, fig. 10.

VAN NAMe (1918): U.S. Nat. Mus, Bull. 100, Vol. 1, Pari 2, pp. 155-159, Figs. 107 \& 108.

HARTMEYFR. (1919) : Kungl. Sv. Vetens. Handi., Bd. 60, No. 4, pp. 136-144.

A large colony, $115 \mathrm{~mm} \times 30 \mathrm{~mm}$ in extent and $1.5-2.0 \mathrm{~mm}$ in thickness, was found by Mr. R. WADA. It is white in colour on account of the existence of small calcareous spicules which are distributed very densely and evenly throughout the whole layers of the colony. They are smaller than $27 \mu$ in diameter and composed chiefly of truncate rays, although a small part of them are consisting of sharply pointed rays. Spicules with truncate rays: spicules with pointed rays is about $8: 1$. Many small elevations of these spicules are found on the surface of the colony. The margin of the colony is extremely thin and forms irregular lobes. Cloacal apertures found sparsely; they are small and round? in outline.

Zooid: Colourless in the preserved specimen. Zooids scarcely reach 2 $\mathrm{mm}$, usually less than $1.7 \mathrm{~mm}$ in length. Thorax is nearly as long as abdomen. Branchial aperture 6-lobed.

Thorax: About 8 longitudinal muscular bands on each side of the thorax. Branchial sac with 4 rows of stigmata, each consisting of 11-13 elongate stigmata. Tentacles 12, 6 larger and 6 smaller. Dorsal languets slightly displaced on the left side from the dorso-median line. Ciliated groove a round orifice. A round thoracic organ on each side of the thorax near the anus which opens 
at the postero dorsal corner of the thorax and with two lobules.

Abdomen: Rectum crooked sharply at the level of the halfway of the middle-intestine. Circum-intestinal gland distinct, being composed of ca. 10 finger-shaped blind sacs. Gonad not found in any zooid. Many round bodies (Fig. 3-6) are found in the colony. They are considered as liberated thorases from old zooids, new thorases of which develope from outgrown buds on their oesophagus? as shown in my previous article (1949) on L. komaii. These bodies seem to be in a resting state before regeneration.

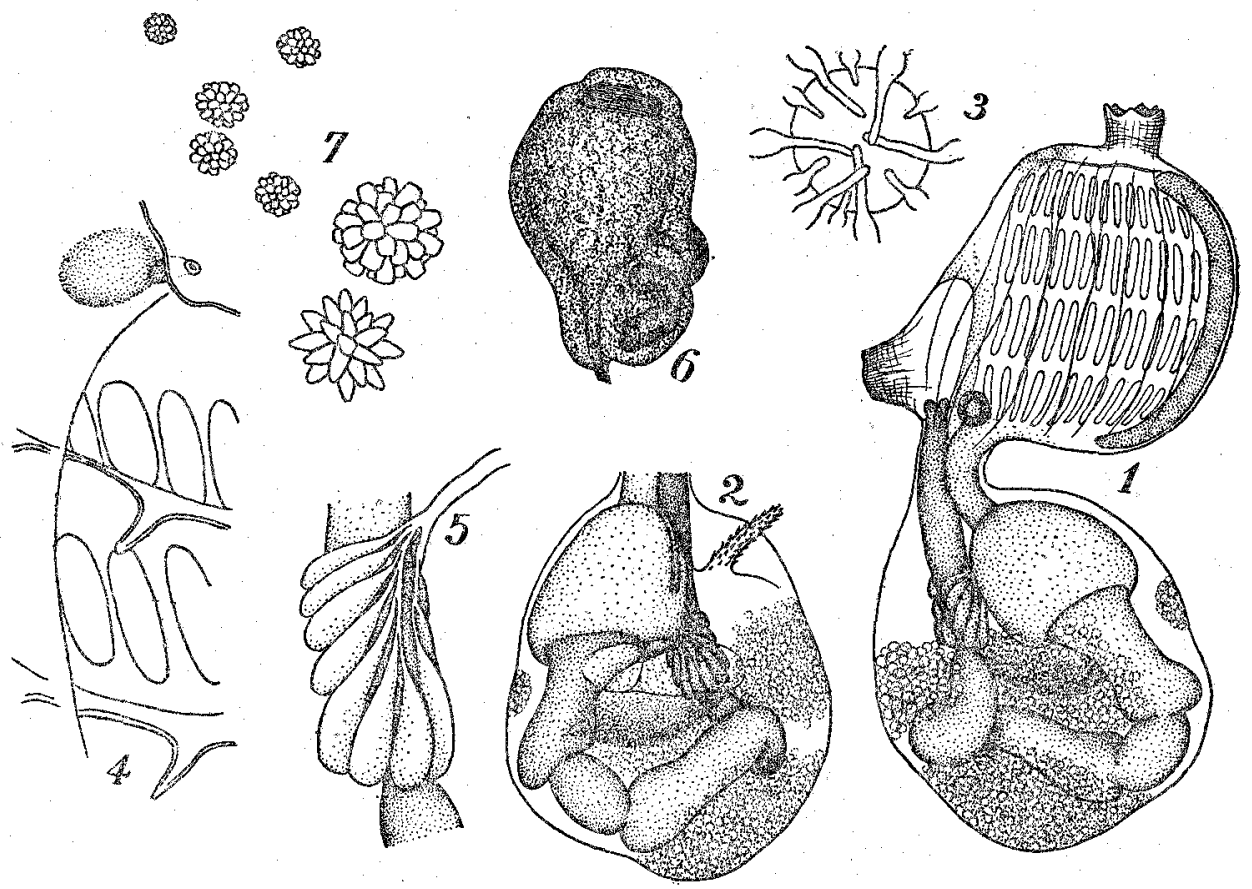

Fig. 3. Lepiocinides dubius (SLUTTER). 1-Zooid $\times 45,2$-Abdomen $\times 45,3-$ Tentacles $\times 110$, 4-Ciliated groove and dorsal languets $\times 110$, 5-Circum-intestinal glend, 6 -Resting thorax before regeneration $\times 45,7$-Spicules $\times 200$.

Remarks: The shape of the calcareous spicules and the sharply crooked appearance of the rectum place the present specimen near Polysyncraton dubium, a Siboga species reported from the Siboga area and from the Philippines. It is, however, not impossible that the preceding species is not a distinct species but merely a form of the present species. 


\section{Pol ycitor renzi-wadai n. $\mathrm{sp}$.}

(Fig. 4)

A roughly spherical mass, $20 \mathrm{~mm}$ long $\times 15 \mathrm{~mm}$ wide $\times 17 \mathrm{~mm}$ high, was

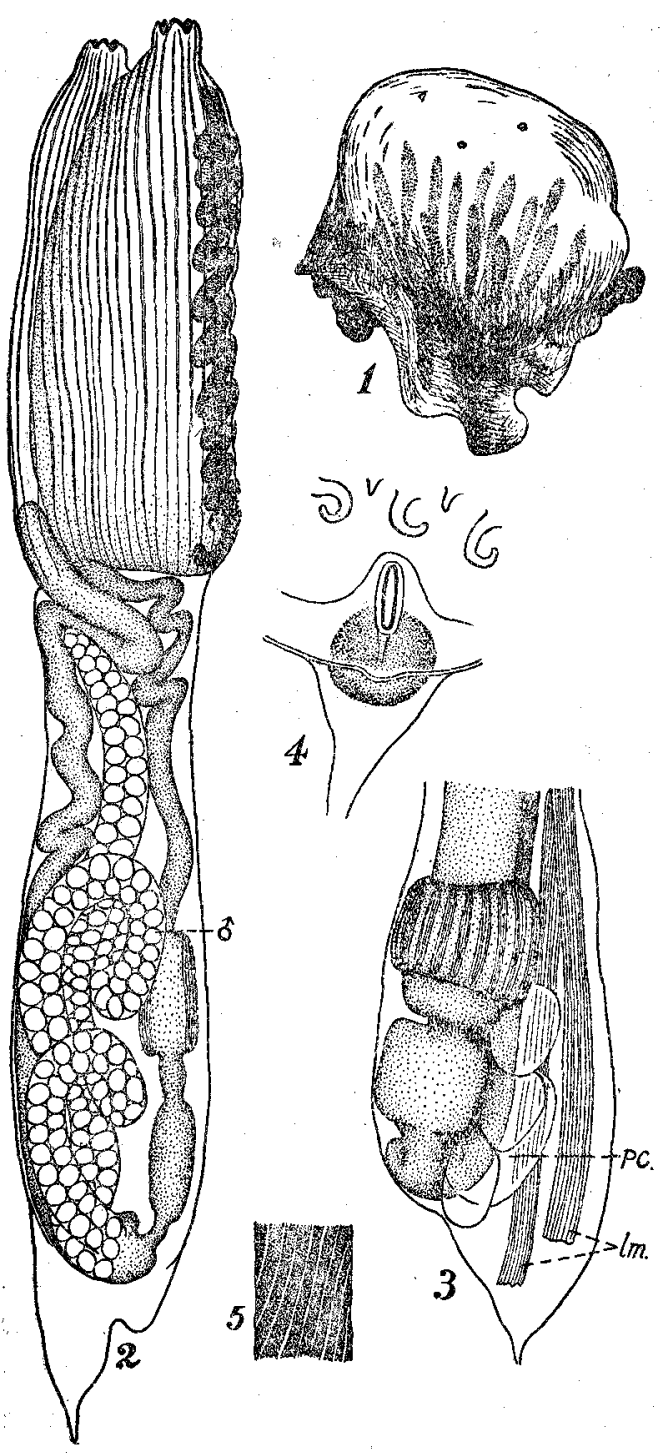

Fig, 4. Polycitor renzi-wadai n. sp. 1-Entire colony, 2-Zooid, 3-Abdomen,. 4-Ciliated groove $\times 45,5-A$ part of the intestinal plication. pc.-Pericardium, Im-mongitudinal muscle band. found by Mr. R. WADA. The basal portion of the colony spreads out slightly and adheres to the substratum by this area. Test cartilaginous, milky white in colour and semitransparent; the surface smooth and without any foreign matter, but merely a little amount of sand grains.

Zooid: Less than $7 \mathrm{~mm}$ in length. Abdomen one and half times the length of the thorax. Both apertures 6-lobed.

Thorax: About 20 thin longitudinal muscular bands on each side of the thorax. Branchial sac with 15-20 stigmata rows. Anus opens near the posterior end of the thorax. Two tentacular rings are observable. The anterior one consisting of 6 small tentacles, while the posterior one consisting of 6 larger tentacles. Dorsal languets distinct. Ciliated groove a longitudinal slit.

Abdomen: A pair of longitudinal muscular bands run along the ventro-sinistral side of the abdomen. Stomach situated siightly behind the half-way of the abdomen and provided with 7-8 plications on each side. The junction between the rectum and the mid-intestine is constricted 
very prominently. Consequent'y the proximal portion of the rectum form a sort of indistinct coeca. Fifteen-twenty faint intestinal plications are found along the rectum, starting from the proximal portion and extending for a considerable distance. Only the male gonad was observed in some examined zooids. In mature state, a thick tube, filled with many small testicular follicles, run sinuously in the loop of the alimentary canal.

Remarks: The present new species resembles closely $P$. auranitiacus (HERDMAN) in having many stigmata-rows on the branchial sac, but differs distinctly from the latter in the appearance of the stomach, the wall of which in the latter is nearly smooth, but with many faint papillae arranged in a net-work.

\section{Clavelina (Synclavella) arafurensis n. sp.}

(Fig. 5)

A colony consisting of about a dozen elongate cormidia was found by Mr. S. WADA. Each cormidium contains about a dozen zooids and may reach $23 \mathrm{~mm}$ in length and $6 \mathrm{~mm}$ in diameter in maximum. Corona, the distal part of the cormidium, is very soft and easily mutilated, while the peduncular and basal portions are considerably hard, semitransparent and faintly pinkish in colour.

Zooid: Large zooids reach $16 \mathrm{~mm}$ in length and light red in colour. Abdomen one and a half times the length of the thorax. Both branchial and atrial apertures plainiy margined or faintly 6-lobed?

Thorax: Transverse muscular bands rather distinct. Branchial sac with 16 stigmata-rows, each row consisting of ca. 20 stigmata. Tentacles $32 ; 8$ large, 8 moderate and 16 small ones are arranged roughly in two circles. Ciliated groove a longitudinal slit. Dorsal languets somewhat triangular in shape. Anus bilobed and situated at the dorso-posterior corner of the thorax.

Abiomen: Stomach near the posterior end of the abdomen, with 5-6 ? plications running longitudinally on the right side and those of the same number arranged somewhat obliquely on the left side. The mid-intestinal portion is present, but not remarkable. Gonad near the posterior end of the loop of the alimentary canal. A pair of longitudinal muscular bands along the left side.

Remarks: The appearance of the colony and the shape of the cormidium are the characteristics of the present new species. 


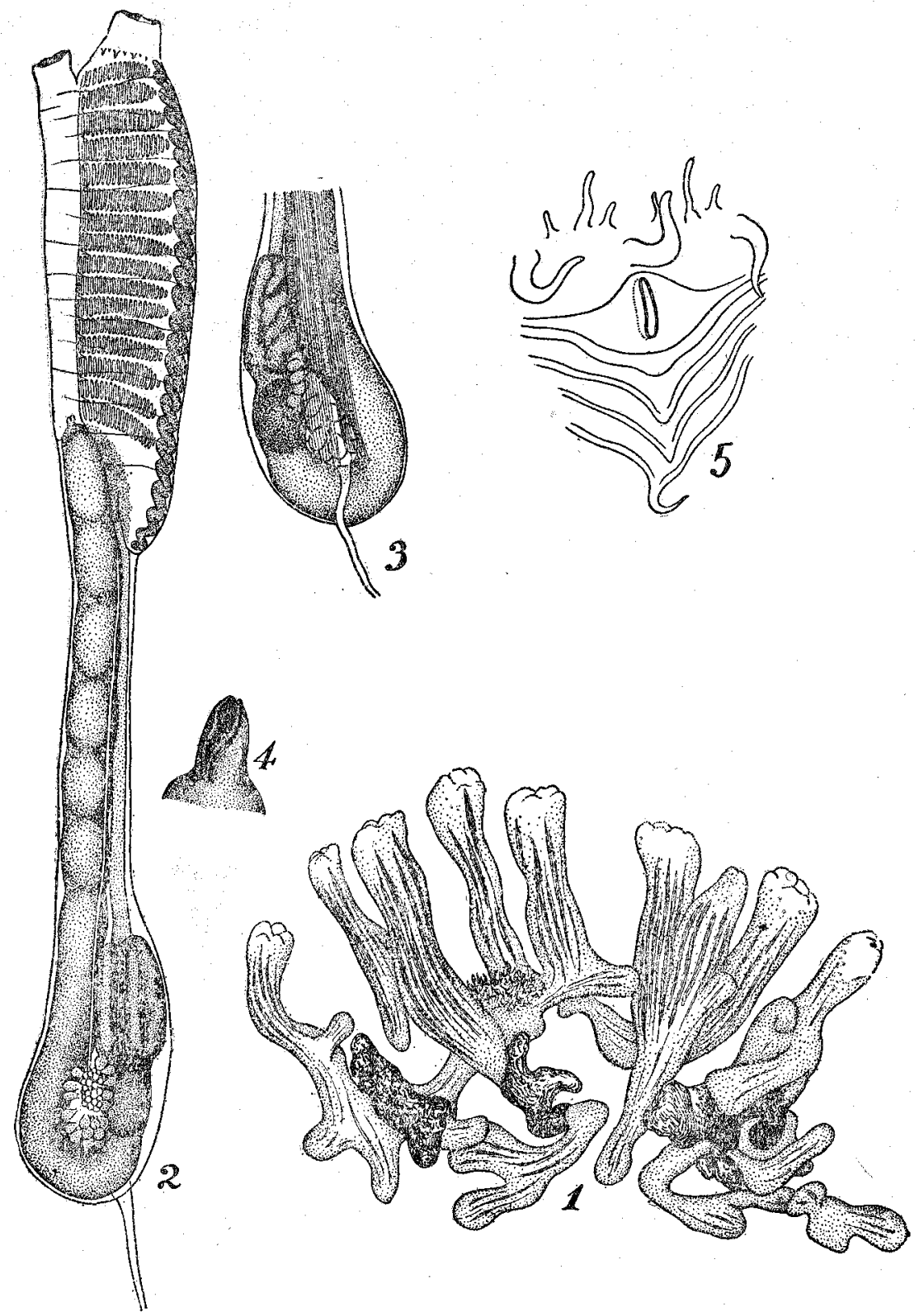

Fig. 5. Clavelina (Synclawella) arafurensis n, sp. 1-Entire colony, 2-Zooid, right side $\times 12$; 3-Posterior part of abdomen, left side $\times 12 ; 4$-Anus, 5-Tentacles, ciliated groove and dorsal languets $\times \Delta 5$. 
6. Sycozoa seizi-wadai n. sp.

(Fig. 6)

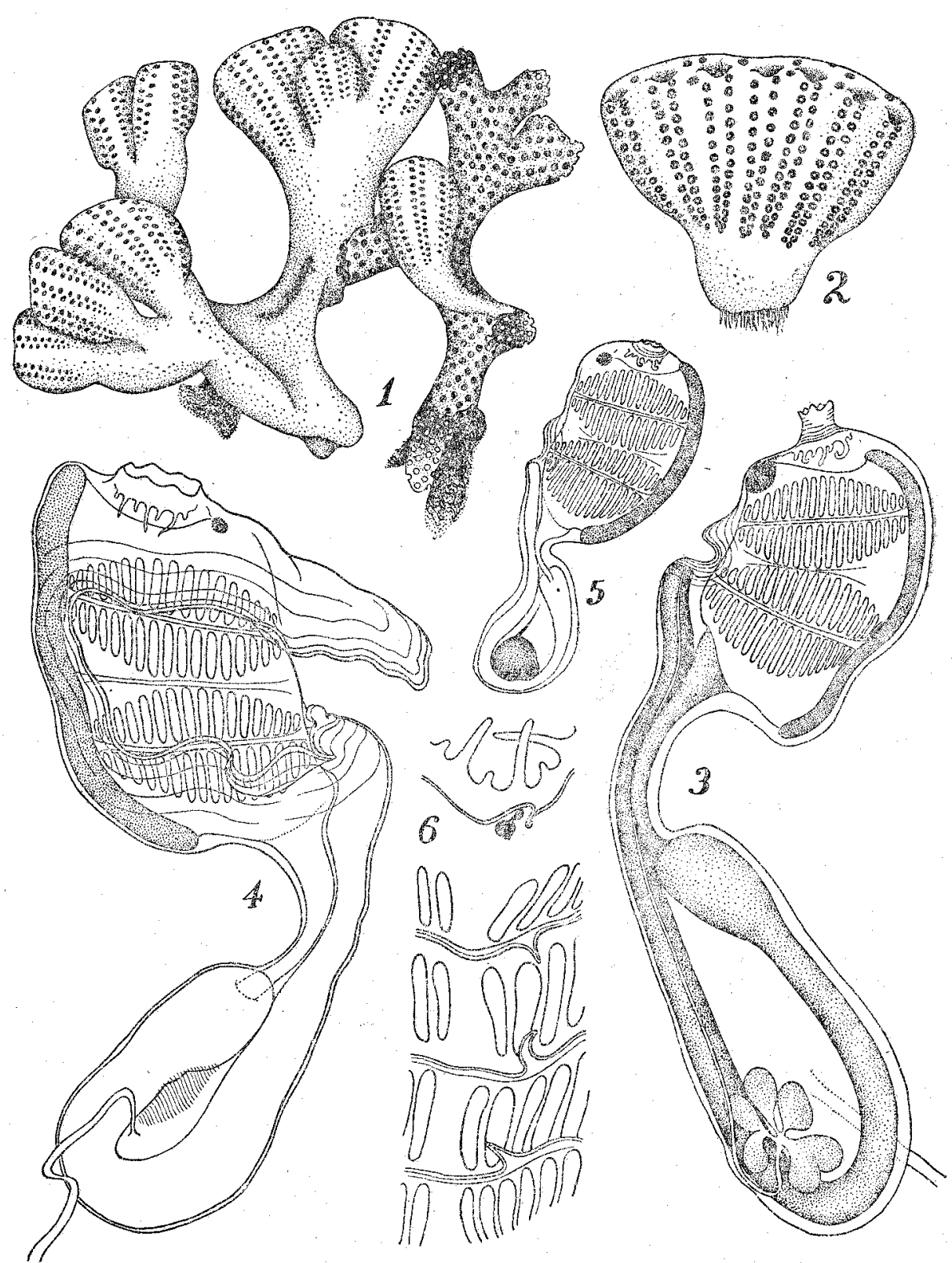

Fig. 6. Sycozoa ssizi-uadai n. sp. 1- Entire colony $\times 1$, 2-A cormidium, enlarged; 3-A sinistral zooid, right side $\times 45 ; 4-A$ sinistral zooid, left side $\times 45 ; 5-A$ young $z 00: \mathrm{d} \times 45,6-$ Tentacles and dorsal languets $\times 45$. 
One colony consisting of 9 cormidia was found by Mr. S. WADA. The largest cormidium $24 \mathrm{~mm}$ wide $\times 12 \mathrm{~mm}$ high and $6 \mathrm{~mm}$ in thickness. Test semitransparent and sprinkled with many milky white flecks on the distal parts of some cormidia. Pinkish in life? Zooids arranged in paired rows as shown in Fig. 6- 1 and 2. Cloacal aperture at the distal end of each pair of vertical rows.

Zooid: Zooids are colourless in the preserved state and less than $3 \mathrm{~mm}$ in length. In fully grown zooids, the abdomen is larger than the thorax. Branchial aperture 5-6 lobed.

Thorax: Thoracic muscular bands very weak. Branchial sac with 4 stigmata-rows, each row consisting of ca. 15-20 stigmata. Tentacles 12, consisting of larger and smaller ones. Ciliated groove a minute orifice. Dorsal languets displaced slightly to the left side from the dorso-median line. Anus with two lobules and situated at the level between the third and fourth stigmata-rows.

Abdomen: Loop of alimentary canal rather simple. Stomach near the mid-way of the abdomen and constricted off distinctly from the oesophagus, while it tapers posteriorly to the intestine without forming any mid-intestinal portion. In the present colony, no zooid was found with the ovary. Testis in the posterior part of the intestinal loop and consisting of several follicles.

Remarks: The shape of the cormidium and consequently that of the colony are the characteristics of this new species.

\section{Nephtheis fascicularis (DRASCHE) 1882}

(Fig. 7)

Colella ihomsoni: HaRdMAN (1886): Rep. Voy. Challenger, Vol. 14, Tunicata, pp. 94-103, PI. X-XIII.

Nephtheis thomsoni; SLUiTer (1909): Siboga-Exped., Monogr. 56 b, p. 36.

HARTMEYER (1919): Kungl. Sv. Vetensk. Handl., Bd. 60, No. 4, p. 121.

Nephtheis thompsoni; VAN NAME (1918): U.S. Nat. Mus. Bull. 100, Vol. 1, Part 2, pp. 144-147, Fig. 96.

Three colonies were available to the present description. Two of them. were collected by Mr. R. WADA at the "Zyûmonzi" (=Cross) Reef off Melville on Oct. 22,1940 . One consisting of $30 \mathrm{~mm}$ long cormidium and $50 \mathrm{~mm}$ long peduncle and matured sexually; the other consisting of $18 \mathrm{~mm}$ long cormidium and $30 \mathrm{~mm}$ long peduncle and sexually immature. One of the three was found by Mr. S. WADA. It is $19 \mathrm{~mm}$ in length of cormidium, $34 \mathrm{~mm}$ in length of peduncle and matured sexually. Test of the cormidium transparent and gelatinous. 


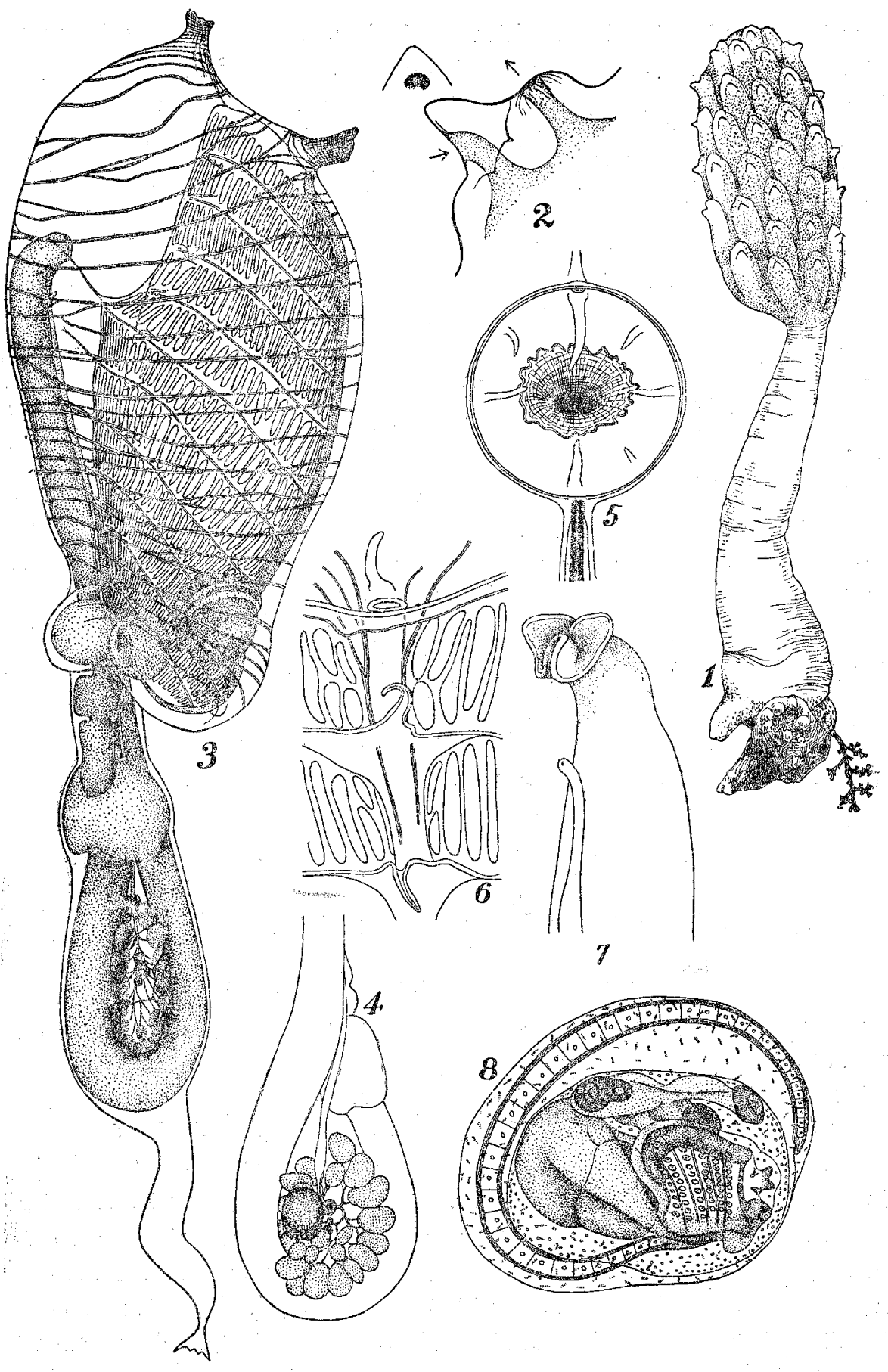

Fig. 7. Newhtheis fascicularis (DRASCHE). 1-A colony xica. 1,2-Situation of apertures 3-Zooid, right side $\times 10 ; \quad 4-A b d o m e n$, left side $\times 10 ; \quad 5$-Tentacles, 6-Ciliated. groove and dorsal languets $\times 40,7$-Anus $\times 42,8-\mathrm{Larva} \times 40$. 
Peduncle somewhat hard and with some hydrozoans and didemnids etc. on the surface. The smallest colony consisting of ca. 30 zooids, while two other colonies are composed of many zooids arranged roughly in 9 rows, each of which consisting of 7-9 zooids. Branchial aperture opens on each posterior side of the conical protuberances projecting out from the surface of the test. Both apertures faintly divided each in 4 lobes, of which the dorsal-most one of the branchial aperture is the largest.

Zooid: Colourless in the preserved state. Large zooids reach $10 \mathrm{~mm}$ in length. Thorax larger than the abdomen.

Thorax: Transverse muscular bands very distinct. The branchial sac with 11-12 stigmata-rows. Tentacles typically $8 ; 4$ larger and 4 smaller ones, of which usually a smaller one is deficient. Ciliated groove a minute oval opening. Dorsal languets nearly on the dorso-median line. Anus bilobed and situated at the level between the fifth and sixth stigmata-rows. Embryos up to 6 in the incubatory chamber on the right posterior side of the thorax. Trunk of larva is fairly shorter antero-posteriorly than dorso-ventrally. Attachment organs well developed and situated in a triangle.

Abdomen: Oesophagus has a small swelling on its way to the stomach which is situated in the anterior half of the abdomen, roughly spherical in shape and with smooth surface. Mid-intestine quite obsolete. Gonad in the loop of the alimentary canal. Testis consisting of follicles of a considerable number. Ovary situated at the centre of the testis.

\section{Perophora listeri FORBES \& HANLEY 1848}

(Fig. 8)

Perowhora listeri; ALDer \& HANCOCK (1907): The British Tunicata, Vol. II, pp. 155-159, Figs. $85 \& 86$.

SALFI \{1931\}: Pubbl. Staz. Zool. Napoli, Vol. XI, p. 321, Fig. 17.

TOKIOKA (1950): Publ. Seto. Mar. Biol. Lab., I (3), pp. 124-125, Fig. 7.

Twenty-six zooids were found on Clavelina (Synclavella) arafurensis; most of them were more or less mutilated. They are all less than $1.7 \mathrm{~mm}$ in length. Many minute bladder cells spread over the test. Branchial aperture 6-lobed, atrial aperture 7-iobed. Around both apertures many corpuscular cells are aggregated densely. Branchial sac with 4 rows of stigmata, each row consisting of ca. 10 stigmata. Longitudinal vessels 8 on the left, 9 on the right side. Tentacles 19-20. Alimentary canal arranged as in sjecimens from the Palao Islands described by Tokioka (1950), although the anus seems to be situated 
more anteriorly than in the Palao specimens. Gonad is not found in any zooid. Evidently the present specimens are younger individuals of the form of $P$. listeri collected in the Palao Islands.

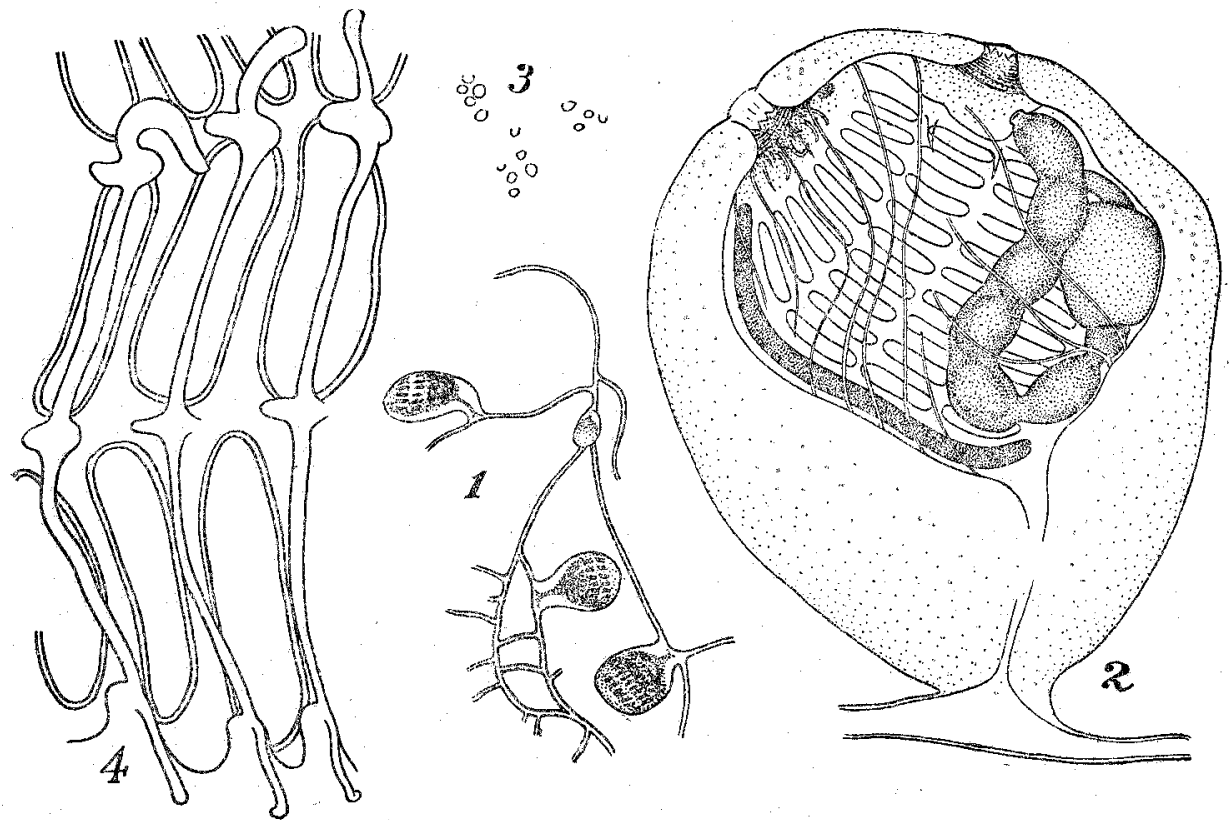

Fig. 8. Perophora listeri FORBES \& HANI.EY. 1-A part of the colony, 2-Zooid $\times 45,3-$ Groups of bladder cells in test $\times 200,4-\mathrm{A}$ part of the branchial sac, from inside $\times 200$.

\section{Ascidia gemmata SLUITER 1895}

(Fig. 9)

Ascidia gemma'a; SLUITER (1895): Semon Zool. Forschungsreisen V, pp. 177-178, P1. IX, figs. 7-9.

HARTMEYeR (1919): Kungl. Sv. Vetensk. Handl., Bd. 60, No. 4, pp. 95-97, Fig. 19, Pl. 2, fig. 49 .

Tokicka (1950): Publ. Seto Mar. Biol. Lab, I \{3), pp. 131-133, Fig. 11, Pl. IX, fig. 2.

Five specimens in all. They are $97 \mathrm{~mm}, 83 \mathrm{~mm}, 74 \mathrm{~mm}, 95 \mathrm{~mm} l o n g$ individuals and one which is much mutilated leaving only the anterior half of the body perfectly. The $83 \mathrm{~mm}$ long individual with enormousiy long atrial siphon. Minute papillae on the test are distinct in smaller individuals, but rather obsolete in larger ones. Branchial ar erture 9, atrial aperture 6-lobed. 


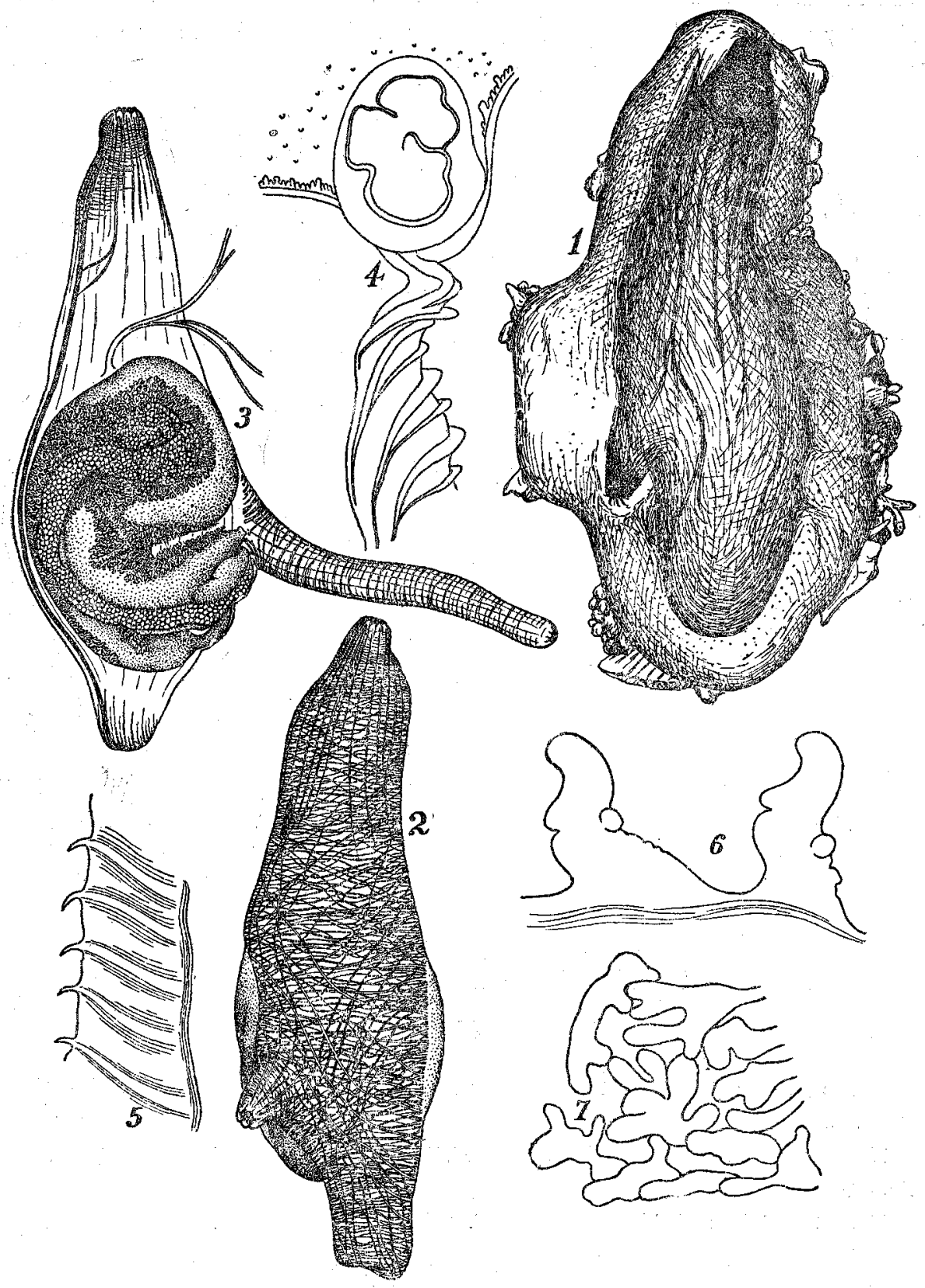

Fig. 9. Ascidia gemmata SLUITER. 1-Entire animal, 2-Right side of the mantle body, 3-Left side of the mantle body with enormously long atrial siphon, 4-Dorsal tubercle $\times 18$, 5-Dorsal lamina $\times 28,6$-Supporting processes of the inner longitudinal vessels $\times 75,7$-Testicular follicles, magnified. 
Both siphons and the anterior part of the branchial sac are coloured in scarlet in life. Dorsal. ganglion is situated slightly in front of the middle of the distance between the branchial and atrial apertures. Five to eicht stigmata in a mesh of the branchial sac which is plicated slightly. Peripharyngeal band fringed anteriorly with minute papillae. Ciliated groove shows rather complex configuration. Tentacles ca. 65 excluding minutes ones, large and small ones alternate with some regularity. They may reach up to 80 in number when we count minute ones together. Differences found between the specimens from Palao and those from the Arafura Sea are considered to be of the individual variation rather than the local variation or the variation according to stocks.

\section{Ascidia sydneiensis STIMPSON 1855}

(Fig. 10)

Ascidia sydaneiensis; HARTMEYER (1919): Kungl. Sv. Veiensk. Handl., Bd. 60, No. 4, pp. 98-99, Pl. 2, fig. 50.

VAN NAME (1921): Bull. American Mus. Nat. Hist, Vol. XLIV, pp. 386-389, Figs. 6265.

VAN NAME (1945) : Bull. American Mus. Nat. Hist., Vol. 84, pp. 189-190, Fig. 101.

Tokioka (1950): Publ. Seio Mar. Biol. Lab., I (3), p. 133, Fig. 12, Pl. IX, fig. 3.

Three specimens were collected by Mr. S. WADA. They are respectively $44 \mathrm{~mm}, 43 \mathrm{~mm}$ and $25 \mathrm{~mm}$ in length and armed sparsely with minute papillae on the test along the margin. Body attached to the substratum by its whole left side. Another two specimens respectively $48 \mathrm{~mm}$ and $23 \mathrm{~mm}$ long, were collected also by Mr. S. WADA. These individuals are provided with many distinct papillae on the whole surface of the test, some of which are represented in Fig. 10-3. Branchial aperture terminal and 8-9 lobed, atrial aperture at the middle of the body on the left margin and 6-lobed. Both siphons vary in length according to the condition of their environment. Mantle musculature restricted to the marginal portion, although in small younger individuals some loose muscular net-work can be seen on the central portion of the right side of the body. Branchial sac with slight plications and with ca. 8 stigmata in a mesh. Transverse vessels are arranged: large-small-medium-small-mediumsmall-medium small-large- --. Tentacles very long and ca. 90 in number. Peripharyngeal band fringed anteriorly with minute papillae. Dorsal tubercle situated far behind the tentacular ring. Dorsal ganglion situated at $1 / 3-1 / 4$ of the distance between both siphons apart from the base of the branchial 

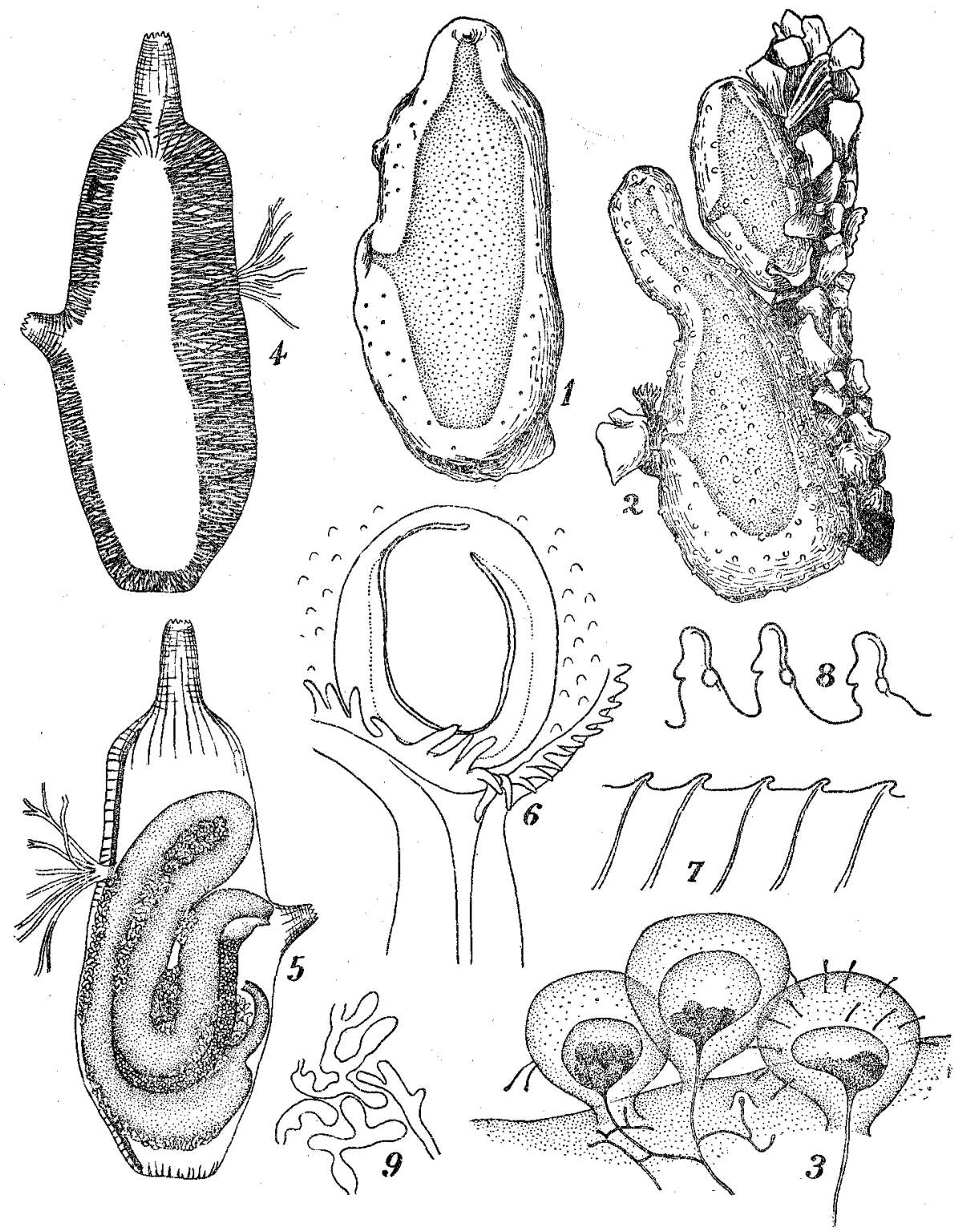

Fig. 10. Ascidia sydneisnsis STIMPSON. 1-Entire animal, 2-Two strongly papillated individuals, 3-Spherical attachment protuberances on the test $\times 12,4$-Right side of the mantle body, 5-Left side of the mantle body, 6-Dorsal tubercle $\times 45,7$-Dossal lamina, 8 -Supporting processes of the inner longitudinal vessels $\times 45,9$-Testicular follicles, magnified. 
siphon. Distance between the dorsal ganglion and the dorsal tubercle about one to two times the length of the ganglion. The anterior ead of the intestinal loop reaches the middle of the distance between both siphons. Rectum is of uniform thickness throughout its whole course.

11. Phal lusia jul inea SLUTTER 1919

(Figs. 11 and 12)

Phallusia julinea; Stuiter (1919): Bijd. Dierk., Aq. XXI, pp. 7-9, Figs. 13-16.

HARTMEYFR (1919): Kungl. Sv. Vetensk. Handl., Bd. 60, No. 4, pp. 99-103, Fig. 20, P1. 2, figs. 51-53.

HASTINCS \{1931\}: Great Barrier Reef Exp., Vol. IV, No. 3, p. 81.

TokioKA (1950): Publ. Seto Mar. Biol. Lab., I (3), pp. 133, 135-136, Fig. 13, Pl. IX, fig. 4.

Three specimens up to $80 \mathrm{~mm}$ in length were collected by Mr. R. WADA and a large specimen, $94 \mathrm{~mm}$ long, by Mr. S. WAdA. They attached to the substratum by their whole left side or by the posterior half or more of the left side. Test white, opaque and without any minute papillae on the surface, except in the smallest $45 \mathrm{~mm}$ long individual. Branchial aperture terminal, slightly bending to the left side and 8-10 lobed. Atrial aperture at the middle of the left margin of the body and 9-15 lobed. Each lobe pectinated and with an ocellus at each interval between the lobes. Mantle white or yellowish brown. In large specimens 11-12 stigmata in a mesh. Sixteen-nineteen thinner transverse vessels between each pair of thicker ones. Supporting processes of the inner longitudinal vessels are provided with distinct lateral prominences. Dorsal ganglion situated much nearer the atrial siphon than the branchial. Dorsal tubercle rather small. Ciliated groove shows a somewhat complex configuration in some individuals. Peripharyngeal band sparsely with minute papillae in some zooids. Secondary tubercles 20-39 in these specimens. Tentacles 37-66, excluding some minute ones. Anus with 14-17 lobules in some zooids. 


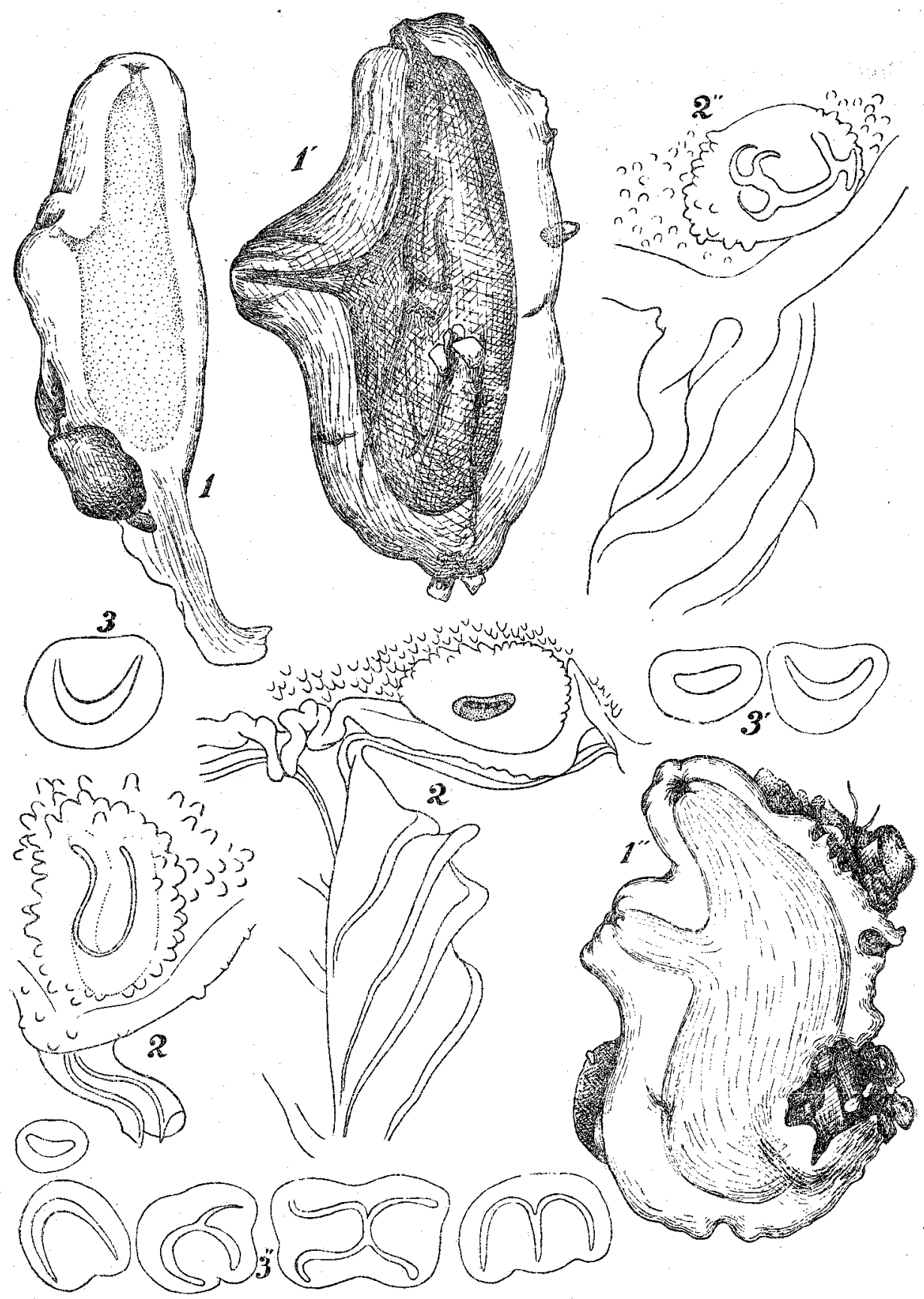

Fig. 11. Phallusia julinea Sluiter. I-3: $45 \mathrm{~mm}$ long individual, 1'-3': $80 \mathrm{~mm}$ long individual, 1"-3": $94 \mathrm{~mm}$ long individual. 1-Entire animal, 2-Dorsal tubercle $\times 45,3-$ Secondary tubercles. 


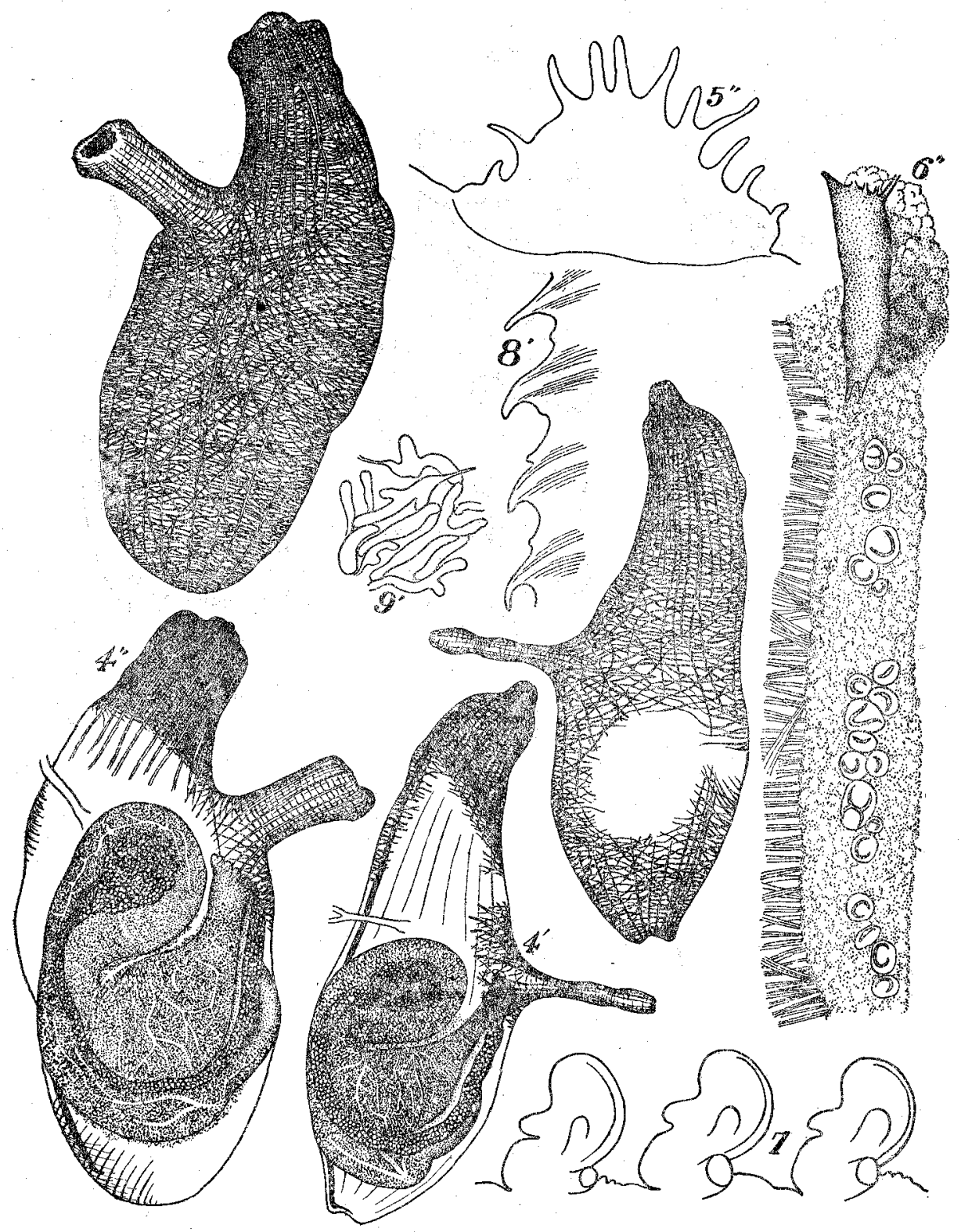

Fig. 12, Phallusia julinea SIUITER. 7:45 mm long individual; 4;,8',9:80 mm long ndividual; 4"-6": $94 \mathrm{~mm}$ long individual. 4-Mancle body, 5-A pectinate lobe of atrial aperture $\times 45,6$-Secondary tubercles $\times 12,7$-Supporting processes ot the inner longitudinal vessels $\times 75,8$-Dorsal lamina $\times 45,9$-Testicular follicles, magnified. 


\section{Phallusia depressiuscula (HELLeR) 1878}

(Fig. 13)
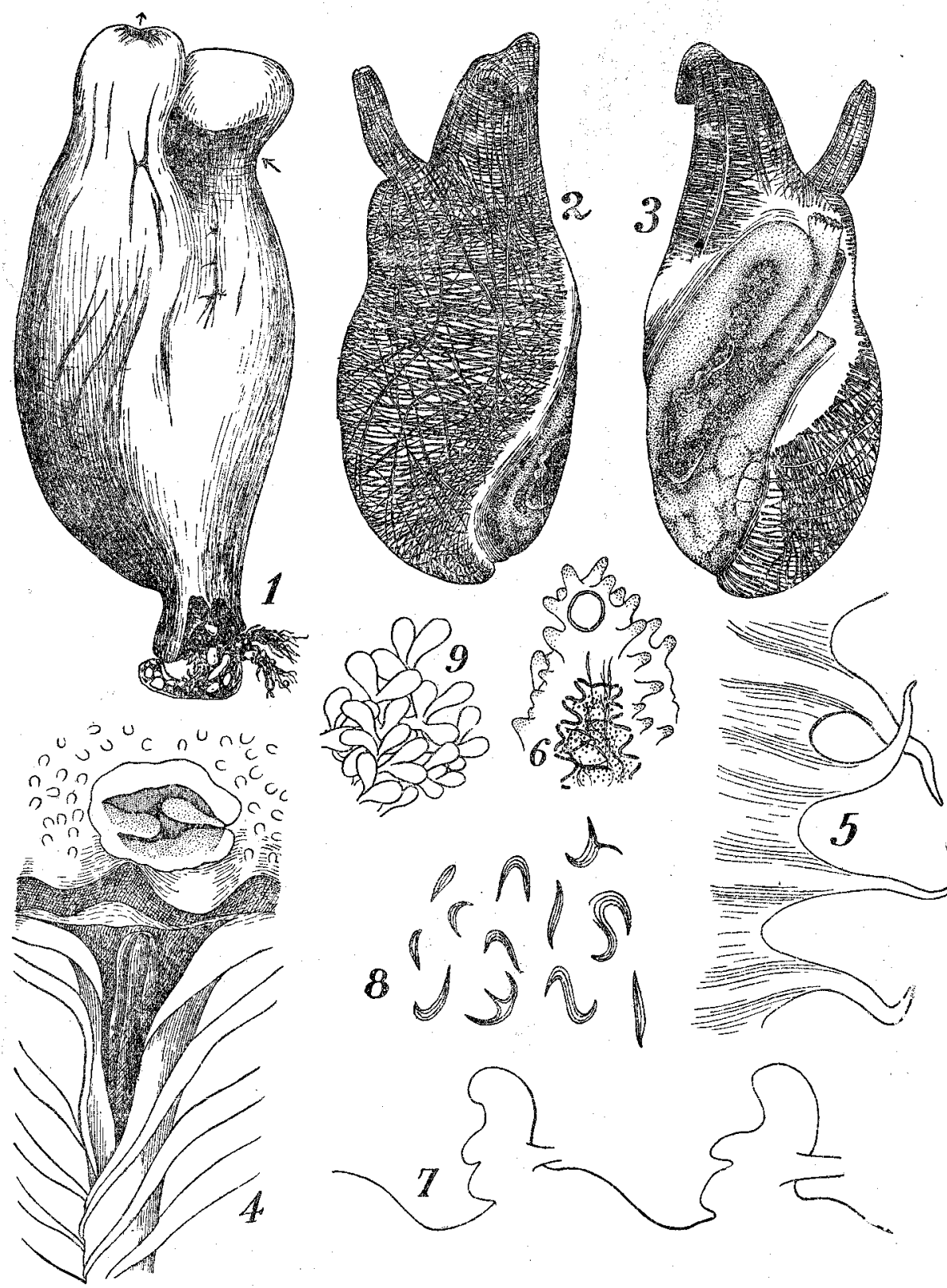

Fig. 13. Phallusia depressiuscula (HELLER). 1-Entire animal, 2-Right side of the mantle body, 3 - Left side of the mantle body, 4-Dorsal tubercle $\times 45$, 5-Dorsal lamina $\times 45$, 6 Section of one of the outer prominences of the branchial sac $\times 55$; 7-Supporting processes of the inner longitudinal vessel $\times 56,8-$ Secondary ciliated grooves $\times 20,9-$-Testicular follicles, magnified. 
Ascidia depressiuscula ; HeRdMAN (1906;: Rep, Ceylon Pearl Oys'er Fish., Pi. 5. Suppl. Rep. No. 39, p. 305, Pl. 2, figs. 10-22.

VAN NAME $\{1918\}$ : U.S. Nat. Mus. Bull. 100, Vol. 1, Pt. 2, pp. 116-119, Figs. 72-74.

HAstiNGS (1931): Great Barrier Reef Exped., Vol., IV, No. 3, p. 80, Fig. 6.

A large, $90 \mathrm{~mm}$. long specimen was found by Mr. S. Wada. Body cylindrical and elongate ovate in outline, attached to the substratum by the posterior end of the body, which is narrowed to a short peduncle-like portion. Anterior part of the body cleft in two siphons of moderate length. Test whitish, semitransparent, cartilaginous and $3-4 \mathrm{~mm}$ in thickness in some thick places. Surface very smooth, although several slight grooves are observable. Mantle pinkish brown, muscular bands on the whole right side. Alimentary canal dark brown. Branchial aperture $12(6 \times 2)$-lobed, atrial aperture 9-lobed.

Branchial sac: Branchial sac plicated and provided on the outer surface with many small papillated protuberances. Supporting processes of the inner longitudinal vessels without lateral prominence. Dorsal lamina is represented by two membranes in the range from the dorsal tubercle to the level of the dorsal ganglion which is situated near the base of the atrial siphon; behind the ganglion these two membranes are united to a membrane with terminally projecting out ribs. Dorsal tubercle very small and with $\mathbf{I}$-shaped ciliated groove. Secondary ciliated grooves very abundant, for instance 67 on the left side, and open directly on the even inner surface of the mantle, without forming any tubercle. Most of them are simple in outline and may reach $500 \mu$ in length in larger ones. Prebranchial area papillated. Tentaclesc a. 80. Most of them are larger, small ones very few in number.

Alimentary system: Anterior margin of intestinal loop does not reach beyond the base of the atrial siphon. The loop long and narrow. Axis of the second intestinal loop passes behind the stomach. Rectum without any swelling. Anus fringed with 14-Iobes, each of which consisting of 2-3 lobules.

Gonad: As in common species of Ascidia.

\section{Rhodosoma turcicum (SAVIGNY) 1816}

(Fig. 14)

Rhodosoma papillosum; TRAUSTEDT (1885): Vid. Meddel. fra naturh. Foren., ann. 1884, p. 9. St.uiter (1904): Siboga Exped., Monogr. 56 a, pp. 26-27, Pl. I, fig. 2, Pl. IV, figs. 4-6. HARTMEYER (1906): Zool. Anz., Vol. 31, p. 25.

HERDMAN (1906): Ceylon Pearl Oyste: Fish., Suppl. Rep., No. 39. p. 302. VAN NAME (1918): U.S. Nat. Mus. Bull. 100, Vol. 1, Pt. 2, pp. 113-116, Figs. 68-71. HART MEYER (1919): Kungl. Sv. Vetensk. Handl., Vol. 60, No. 4, p. 95. 
Rhodosont pollucidum; VAN NAME (1921): Bull. American Mus. Nat. Hist., Vol. 4. , 392-395, Figs. 69-70.

VAN NAME (1921) : Bijd. Dierk. Afl. XXIII, p. 29.

Rhodosoma furcicum; VAN NAME (1945): Bull. American Mas. Nat. Hist., Vol. 84, pp. 203 205, Figs, $116-117$.

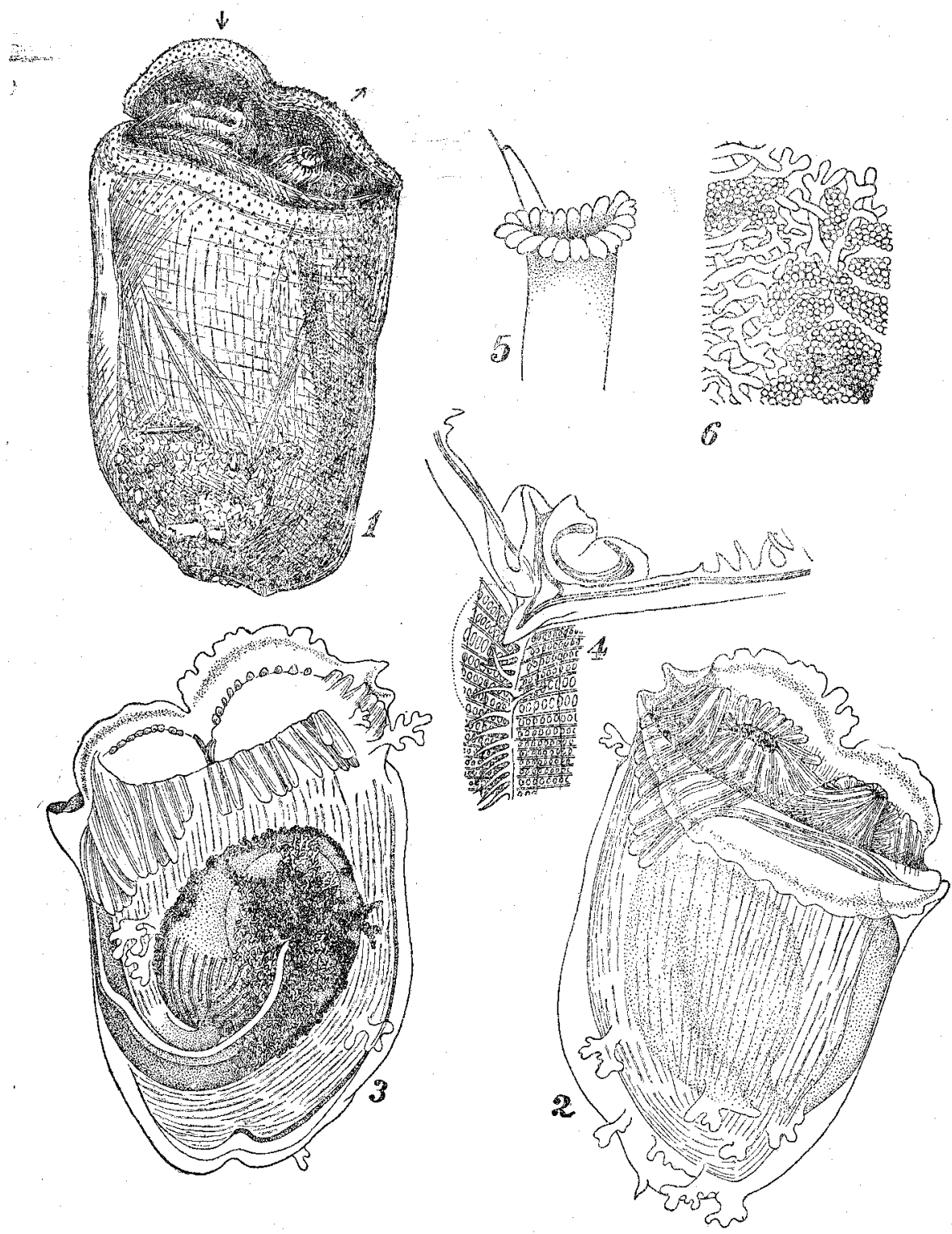

Fig. 14. Phodoroma furcicum (SAVIGNM). 1-Entire animal, 2-Left side of the mantle body, 3-Right side of the mantle body, 4-Dorsil tubercle and dorsal languets $\times 45,5-$ Anus, $6-A$ part of the gonad. 
One specimen of $50 \mathrm{~mm}$ long $\times 33 \mathrm{~mm}$ wide $\times 15 \mathrm{~mm}$ thick, attached to the substratum by its whole right side and with many sponges and hydrozoans on the surface. Branchial aperture 7-lobed, while atrial lobes are quite obscure. About 4 stigmata in a mesh. Anus fringed with ca. 25 lobules.

\section{Stolonica (Amphicarpa) sigma n. sp.}

(Fig. 15)

One colony consisting of ca. 50 zooids was offerrsed to me by Mr. S. WADA. Zooids are comected one another by creeping stolon issued from the posteroventral conner of the animals. Body length $9-12 \mathrm{~mm}$. Branchial aperture terminal, atrial aperture slightly aparting from it. Both apertures 4-lobed; siphons very short. Test of moderate thickness, yellowish white and with many sand grains and other small foreign matters on the surface, especially remarkably on the left side. Mantle rather thick, reddish-brown in colour and adherent to the test. Four dark brown spots around the aperture of each siphon. Several endocarps on the inner surface of the mantle on each side.

Branchial sac: Two folds on each side. Inner longitudinal vesscls arranged as follows:

A large zooid:

$\begin{array}{llllllll}\text { Left } & \text { D. } & 1 & (9) & 3 & (7) & 4 & \text { V. } \\ \text { Right } & \text { D. } & 4 & (8) & 3 & (6) & 6 & \text { V. }\end{array}$

A medium-sized zooid:

$\begin{array}{llllllll}\text { Left } & \text { D. } & 1 & (10) & 4 & (7) & 4 & \text { V. } \\ \text { Right } & \text { D. } & 4 & (9) & 3 & (6) & 6 & \text { V. }\end{array}$

Thick transverse vessels and thin parastigmatic vessels alternate regularly. About 5 stigmata in a mesh. Tentacles 42-50 exciuding minute ones. Ciliated groove a longitudinal slit; small pigment flecks dispersed on the tubercle. Dorsal lamina a plain membrane.

Alimentary system: Alimentary canal curves strongly so as to figure $\mathrm{S}$ on the inner surface of the mantle on the ventro sinistral side. Stomach small and round, with ca. 8 plications on each side. Pyloric coecum absent, while a short vessel connecting the pyloric portion of the stomach to the intestine. Anus plainly margined. A large endocarp in the first intestinal loop. The axis of the second intestinal loop passes the middle of the stomach.

Goadn: Many ovaries, up to 20 , arranged roughiy in a row along the ventral side of the right side and much less ones, about a half of those on the 
right side, along the ventral side of the left side, also arranged in a row. Many oval testes arranged roughly in a group near the dorsal margin on the right side being apart from ovaries, while they are distributed dorso posteriorly to ovaries on the left side.

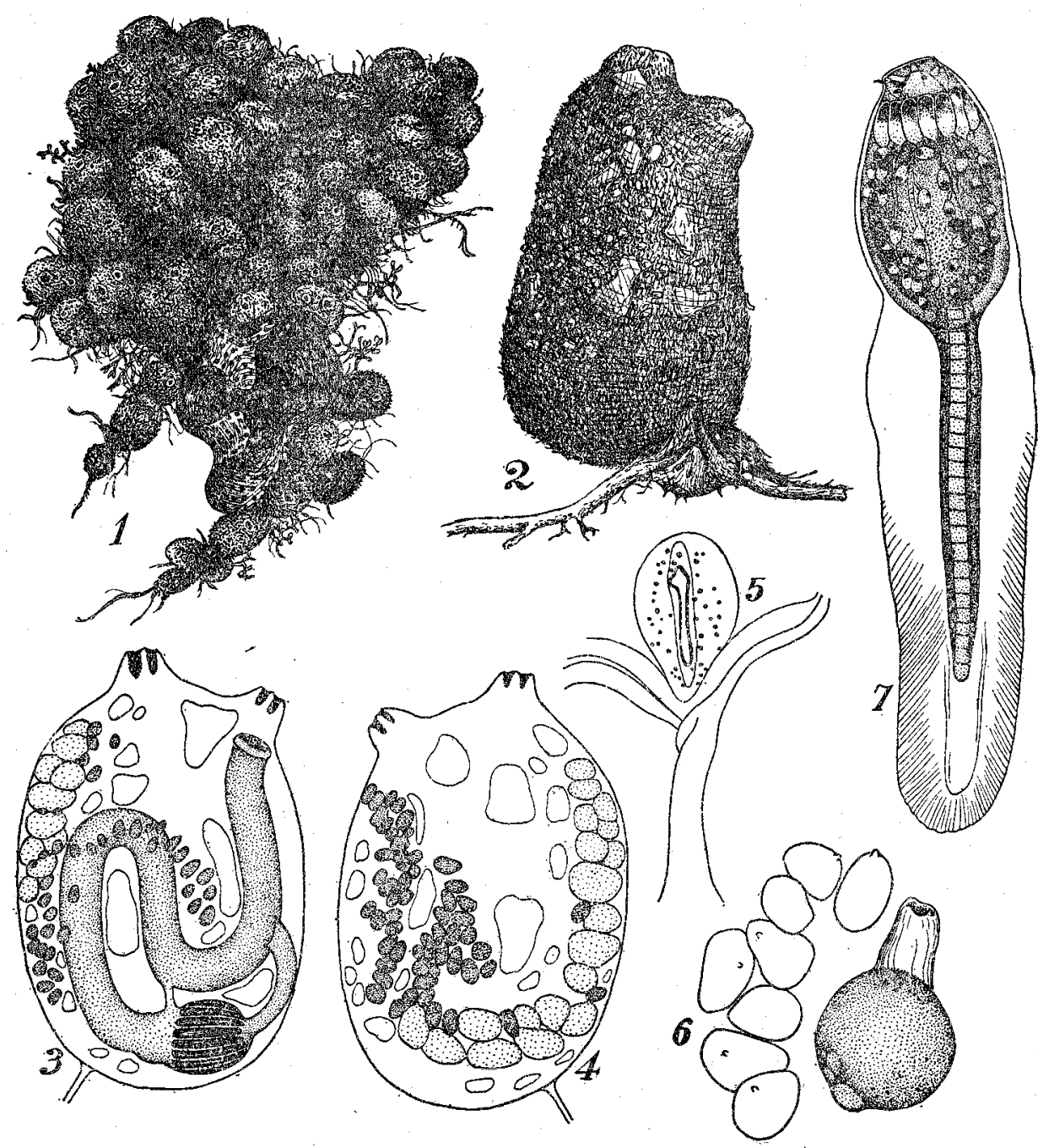

Fig. 15. Stolonica (Amphicarpa) sigma n. sp. 1-Entire colony, 2-A zooid, 3-Left half from inside; 4-Right half from inside, 5-Dorsal tubercle $\times 45$, 6-An ovary and several testes $\times 28,7$-Larva $\times 27$.

Larva: Peculiar larvae, up to 9 in number, found in the peribranchial cavity being situated with their anterior ends towards the endostyle. Much 
more larvae in the right cavity than in the left. The anterior end of the trunk narrowed slightly and with three attachment processes situated in a triangle. Sixteen ampullae situated behind the attachment organs. Each ampulla pigmented darkly at the anterior portion and provided with a vessel running posteriorly, which issues several short branches ending each in a small bulb pigmented distally as in the ampulla, on the way to the posterior end of the trunk.

Remarks: The present new species differs from, its allies, S. styeliformis VAN Name from the Philippine waters, S. duploplicata SLUITER from Aru Islands and Distomus diptychos HARTMEYER from Cape Jaubert, in having the almientary canal curved much more strongly than in these species.

\section{Pol yandrocarpa (Eusynstyela) latericius (SLUTTER) 1904}

(Fig. 16)

Gynandrocarpa latericits; SI.UITER (1904): Siboga-Exped., Monogr. 56 a, pp. 94-95, Pl. XV, figs. 8-11.

Eusynstyela latericius; VAN NAME \{1918; U.S. Nat. Mus. Bull. 100, Vol. 1, Pt. 2, pp. 105-107, Figs. 58-60.

A colony, ca. $30 \mathrm{~mm} \times 40 \mathrm{~mm}$ in extent and ca. $2 \mathrm{~mm}$ in thickness, was found by Mr. R. WADA. Zooid 6-7 mm in length. Branchial and atrial apertures respectively at each terminal. Test rather thick, yellowish white with dark reddish tint around the apertures. The neighbourhood of each aperture swells up to a low dome and with 4 thick and 2 or 4 thin colour bands converging to the aperture. Inner surface of test white, excepting the neighbourhood of the apertures where it is coloured red. Mantle yellow and semitransparent. Atrial tentacles on the atrial velum, especially densely along its margin. A pair of groups of corpuscular cells near the anterior end of the endosyle. Endocarps present; those on the lateral side of the body are all transversely elongate.

Branchial sac: With two distinct and two indistinct folds on each side. They are rather groups of inner longitudinal vessels than the fold. Vessels arranged as follows:

Ist zooid :

\begin{tabular}{|c|c|c|c|c|c|c|c|c|c|c|}
\hline Left & D. & 0 & (9) & 0 & (5) & 0 & (17) & 0 & (10) & 0 \\
\hline Right & D. & $\theta$ & (14) & 0 & (5) & 0 & (13) & 0 & (4) & 0 \\
\hline
\end{tabular}


2nd zooid:
Left
D. 0 (11)
0
(8)
0
(14)
0
(8) $0 \quad \mathrm{~V}$.
Right
D. 0 (14) 0
(6) 0
(14) 0
(7) $0 \mathrm{~V}$.

3rd zooid:
Left
D. 0 (12)
0
(7) 0
(15) 0
(9) $0 \mathrm{~V}$.
Right
D. 0 (13) 0
(7) 0
(14) 0
(3) $0 \mathrm{~V}$.

Folds I and III are distinct. As the formation of the fold is incomplete, the distinction between the intermediate longitudinal vessels and those on the folds is rather obscure. Transverse vessels arranged-thick-thin-thick-thin - Parastigmatic vessels found only rarely. Stigmata-rows ca. 20. Stigmata in a mesh less than 5, usually ca. 4. Tentacles reddish brown in colour and consisting of 6-8 large and 3-6 small ones. Ciliated groove a longitudinal slit. Dorsal lamina with thickened brownish margin.

Alimeniary system: Alimentary canal situated in the posterior half of

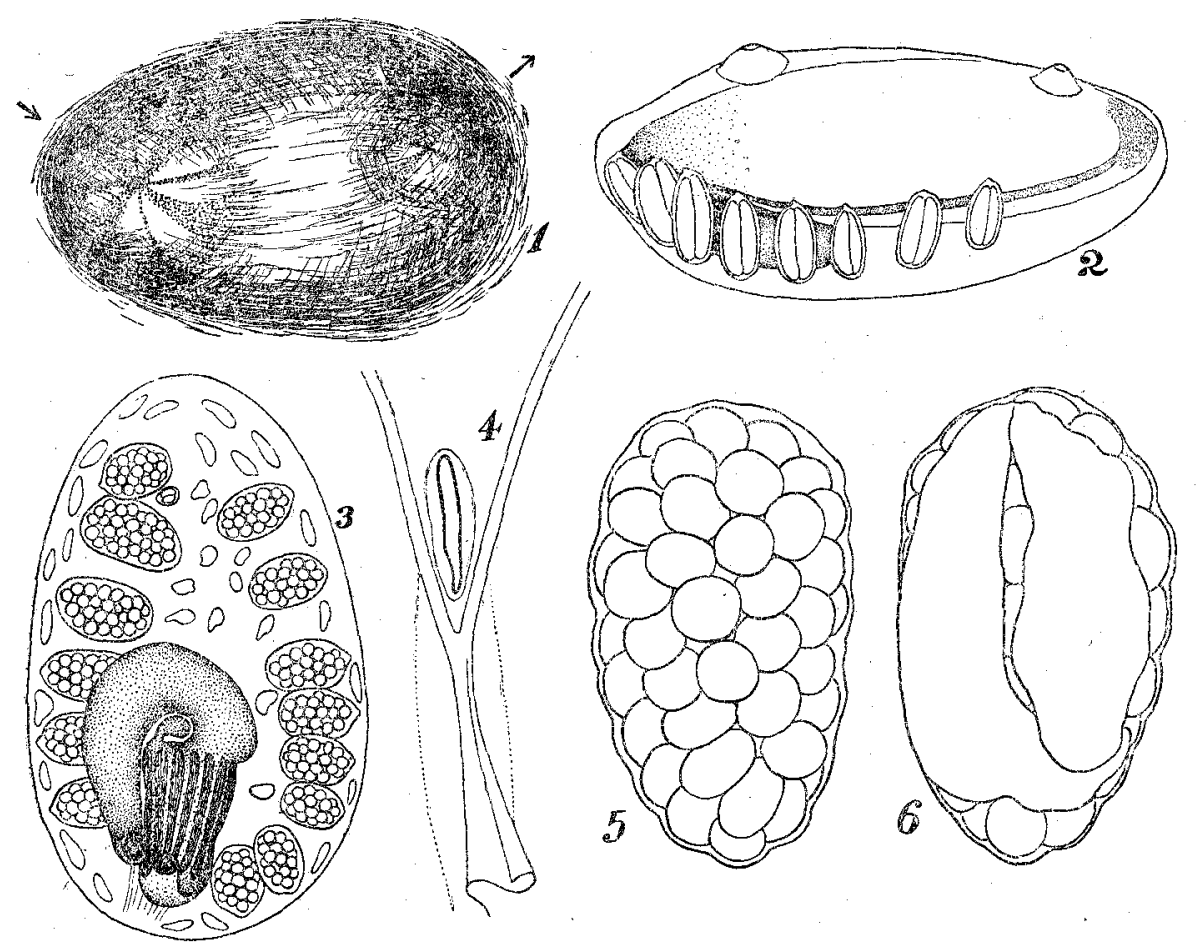

Fig. 16. Polyandrocarpa (Eusynsiyela) la'ericius (SIUTTER, I-A zooid from dorsal, 2-Mantie body from right side, 3-Ventral half from inside, 4-Ciliated groove $\times 45,5$-Gonad free surface $\times$ ca. 30 ; 6 - Gonad, attachment surface $\times$ ca. 30 . 
the ventral side of the body. Loop simple. Stomach a half of the length of the loop and with a distinct pyloric coecum and about 7 plications on each side. Anus with brownish, thickened and undulating margin, but without lobation.

Gonad: Seven to ten hermaphroditic gonads on each side. Each gonad elliptical in shape and with two testicular follicles on the side of attachment.

\section{Polycarpa papillata (SLUITER) 1886}

(Fig. 17)

Styela papillata; SLUTTER (1886\}: Natuurk. Tijdschr. Ned.Ind., XLV, pp. 192-19ö, Pl. 1> fig. 8 , Pl. 5, figs. $1-4$.

SLUiter (1891): Natuark. Tijdschr. Ned.-Ind., L, p. 333.

Three specimens, respectively $60 \mathrm{~mm}, 35 \mathrm{~mm}$ and $23 \mathrm{~mm}$ in length, were collected by Mr. R. WADA. The smallest one is oval in shape, while other two individuals are rather elongate and each with a posterior peduncle-like extension of the body. Branchial aperture terminal; atrial aperture slightly in. front of the middle of the body or body proper, the posterior base of the thick dome-like atrial siphon at just the middle of the body. Both apertures 4-lobed. Body attached to the substratum by its right and posterior side. Test not thick, but very tough, grayish yellow to yellowish brown in colour and with many irregular grooves on the surface in the largest specimen. In the medium-sized individual, test rather smooth except the neighbourhood of the apertures, where it is furnished with grooves. The smallest one adheres a small amount of foreign matters on its surface which is grooved irregularly, especially around the apertures. Mantle yellow to orange; both siphons dark red, brown or grayish yellow. Inner surface of test slightly pale in colour. Many minute atrial tentacles on the inner surface of the atrial siphon. Many. endocarps on the inner surface of the mantle.

Branchial sac: Inner longitudinal vessels as follows:

$60 \mathrm{~mm}$ long individual:

$\begin{array}{llllllllllll}\text { Left } & \text { D. } & 5 & (14) & 6 & (17) & 6 & (16) & 6 & (13) & 5 & \text { V. } \\ \text { Right } & \text { D. } & 5 & (15) & 6 & (16) & 5 & (14) & 5 & (12) & 6 & \text { V. }\end{array}$

$23 \mathrm{~mm}$ long individual:

$\begin{array}{llllllllllll}\text { Left } & \text { D. } & 3 & (15) & 3 & (14) & 3 & (13) & 3 & (12) & 3 & \text { V. } \\ \text { Right } & \text { D. } & 3 & (14) & 3 & (14) & 3 & (14) & 3 & (12) & 3 & \text { V. }\end{array}$

About 3 thin transverse vessels between a pair of thicker ones. Parastigmatic vessels present. Five to eight stigmata in a mesh. Papillae found by 


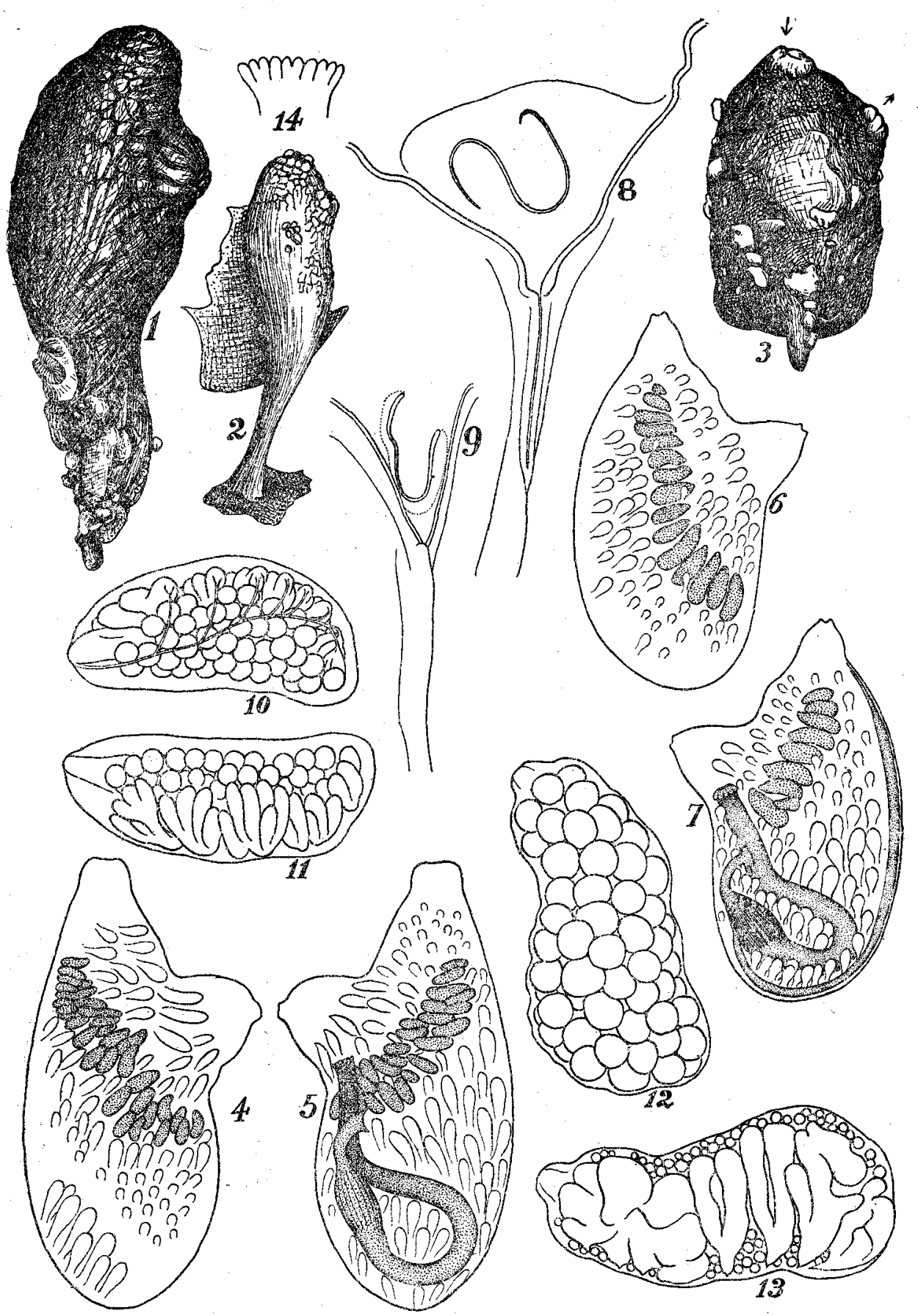

Fig. 17. Polycarpa papillata (SLUTIER). 1-60 $\mathrm{mm}$ long individual, left side; $2-35 \mathrm{~mm}$ long individual, left side; $3-23 \mathrm{~mm}$ long individual, left side. $4,5,8,10,11,14-60 \mathrm{~mm}$ long individual, $6,7,9,12.13-23 \mathrm{~mm}$ long individual. 4 -Right half from inside, 5-Left half from inside, 6-Right half from inside, 7-Left half from inside, 8-Ciliated groove $\times 28,9$-Ciliated groove $\times 45$. 10-Gonad, free surface $\times 14 ; 11$-Gonad, atiachment surfaee $\times 14 ; 12$-Gonad, free surface $\times 28 ; 13$-Gonad, attachment surface $\times 28 ; 14$-Anus. 
SLUITER on the inner surface of the branchial sac quite obscure on my present material. Tentacles 14-21, large and small ones alternate somewhat regularly. Ciliated groove figures U or S-shaped courses.

Alimentary system: Loop of the alimentary canal simple and situated in the posterior third of the body, Intestinal joop rather wide and contains many endocarps therein. Stomach not so thicker than the following intestine; rather faint plications on the surface. Pyloric coecum absent. Anus with 13-16 lobules.

Gonad: In $23 \mathrm{~mm}$ long individual, 10-15 gonads are arranged in a row along the dorsal side of the left half body and along the median axis of the right half-body, while in $60 \mathrm{~mm}$ long individual much more gonads are arranged roughly in two longitudinal rows on each side in the anterior half of the body. Each gonad elliptical and provided with several testicular follicles, each of which ramified into a few lobules.

\section{Pol ycarpa longiformis n. sp.}

(Fig. 18)

Two specimens, respectively $70 \mathrm{~mm}$ and $55 \mathrm{~mm}$ in length, were collected by Mr. S. WADA. Body elongate oval, attached by the posterior end and with siphons at the anterior end of the body, of which the atrial longer than the branchial. Test grayish purple, opaque, cartilaginous and rather thick measuring ca. $2 \mathrm{~mm}$ at many places. Surface smooth, with little grooves. Mantle with well developed musculature, semitransparent and purplish brown in colour. Branchial aperture 6(?)-lobed, atrial aperture 4-lobed. Many endocarps on the inner surface, especially those near the posterior end of the body are prominent.

Branchial sac: Longitudinal vessels arranged as follows in $70 \mathrm{~mm}$ long individual.

$\begin{array}{llllllllllll}\text { Left } & \text { D. } & 5 & (16) & 6 & (17) & 6 & (16) & 6 & (13) & 5 & \text { V. } \\ \text { Right } & \text { D. } & 4 & (18) & 6 & (16) & 5 & (15) & 6 & (12) & 6 & \text { V. }\end{array}$

Three to five thinner transverse vessels between each pair of thicker ones. Parastigmatic vessels present. Five to seven elongate stigmata in a mesh. Tentacles 44 in $70 \mathrm{~mm}$ long individual, and consisting of large, medium, small and minute ones. Ciliated groove S-shaped. Dorsal lamina a plain membrane.

Alimentary system: Loop very simple, with roundish stomach near the 

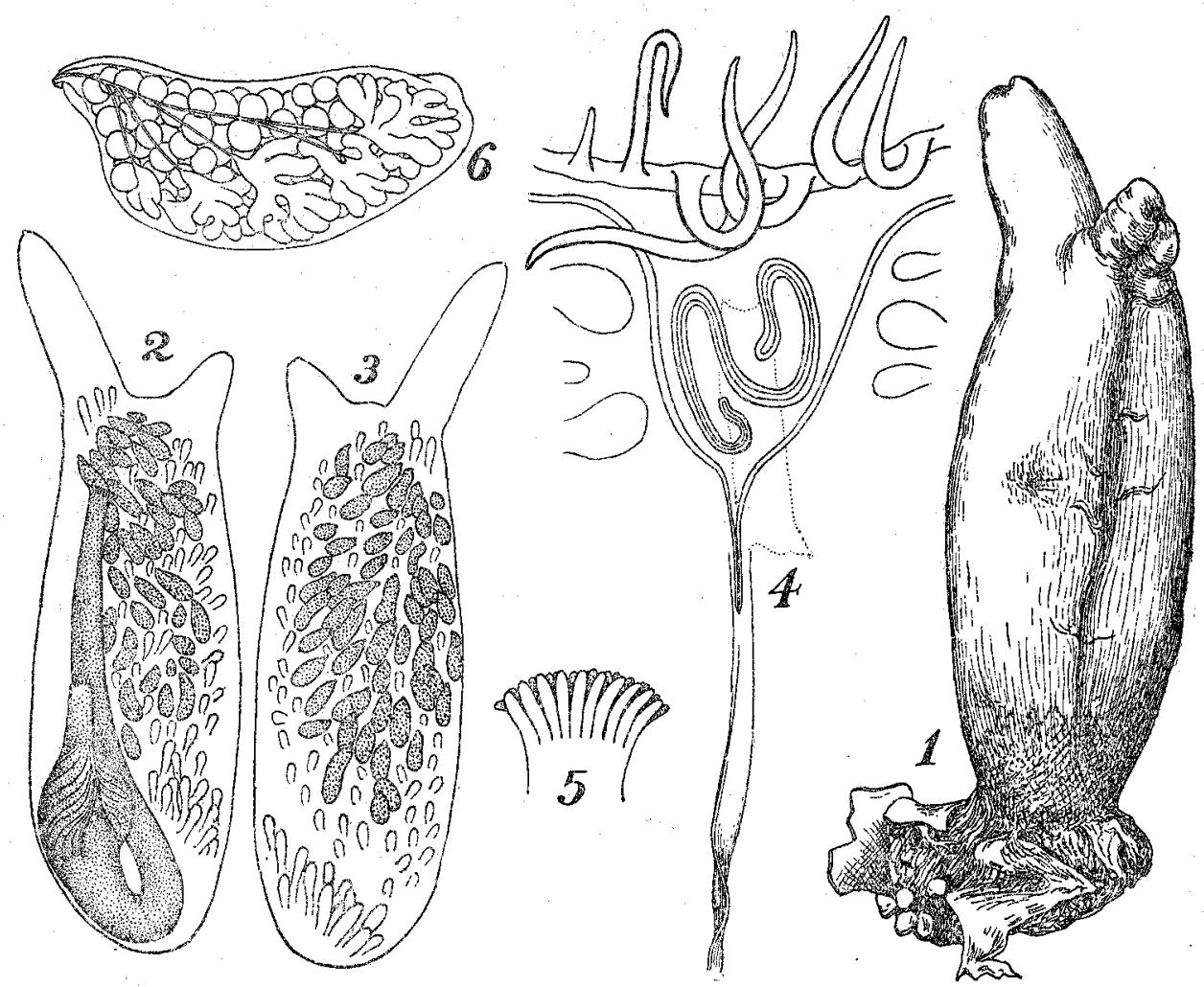

Fig. 18. Polycarpa longiformis n. sp. $1-70 \mathrm{~mm}$ long individual, 2-Left half from inside, 3-Right half from inside, 4-Tentacles and ciliated groove $\times 14,5-$ Anus, 6-Gonad $\times 14$.

posterior end of the body and long rectum. Stomach plicated, but without pyloric coecum. Anus finely lobated.

Gonad: Distributed evenly on the inner surface of each side. Each gonad oval in shape and provided with several testicular follicles which are ramified each in a few lobules.

\section{Polycarpa longicarpa n. sp.}

(Figs. 19 and 20)

One specimen, $14 \mathrm{~mm}$ long, was found on the colony of Stolonica. Besides 


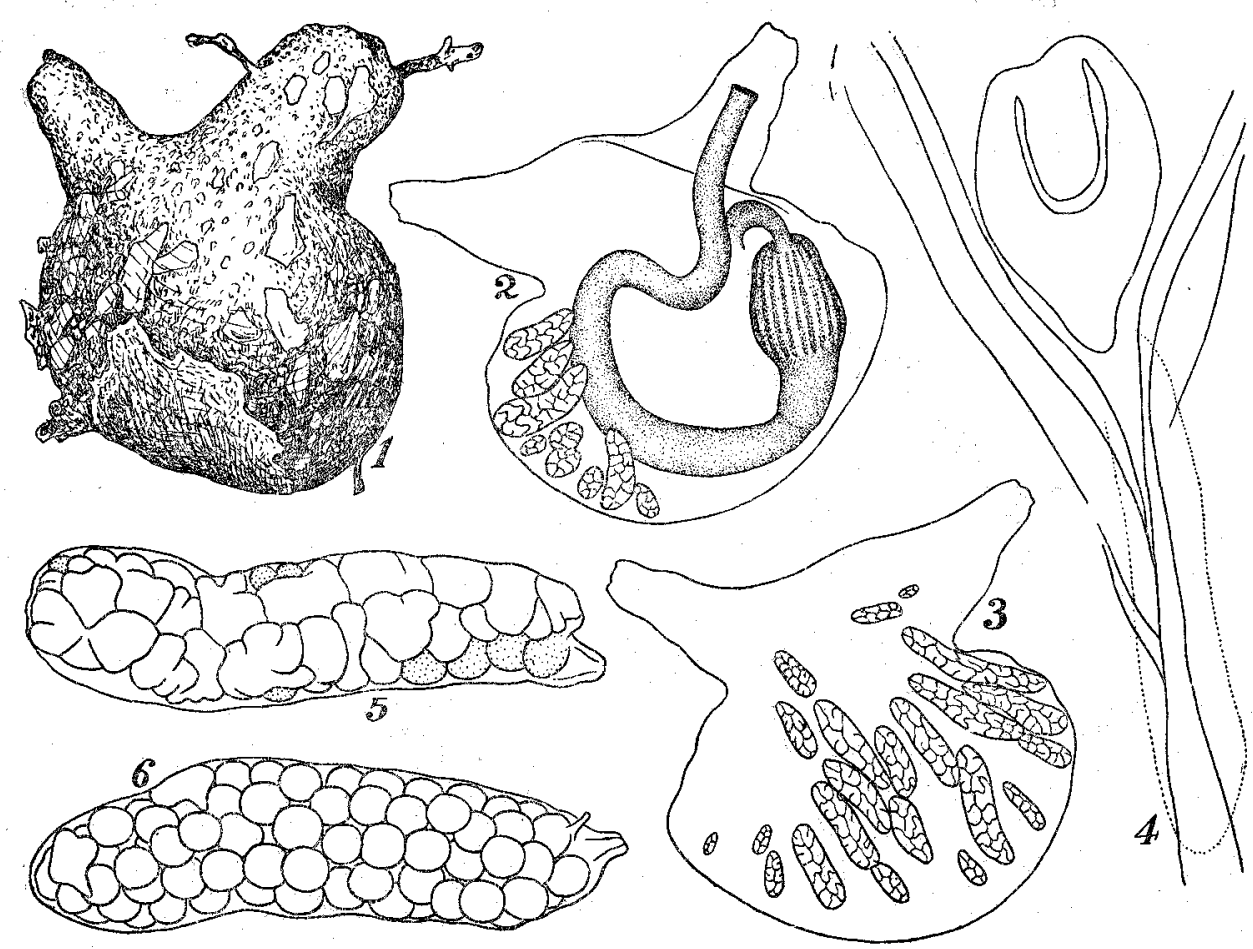

Fig. 19. Polycarpa longicarpa n. sp. 1-Entire animal from right side, 2-Left half of mantle body from outside, 3-Right half of mantle body from outside, 4-Dorsal tubercle $\times 45,5$ Gonad, attachment surface $\times 28 ; 6$-Gonad, free surface $\times 28$.

a young $11 \mathrm{~mm}$ long specimen on a specimen of the preceding species. Body roughly oval in outline, with prominent siphons at the anterior end and attached by its whole left side. Test yellowish white in colour and thin, but very tough and adheres many sand grains and mud on the surface. Both apertures 4-lobed. Mantle thin, translucent and pinkish or light brownish in colour. Siphons of considerable length. Atrial velum well developed.

Branchial sac: Inner longitudinal vessels arranged as follows :

Young individual:
Left
D. 4
(7) 5
(7)
5
(6)
5
(6)
$5 \mathrm{~V}$.
Right
D. 4
(5) 4
(7) 4
(6) 4
(7) $5 \mathrm{~V}$.

Mature individual :
Left
D. 4 (10)
$5 \quad$ (13)
5 (11)
$4 \quad(7)$
$6 \mathrm{~V}$
Right
D. 4 (10)
$5 \quad$ (15)
5 (12)
$6 \quad(10)$
$7 \mathrm{~V}$. 
Three to seven thinner transverse vessels between each pair of thicker ones. Parastigmatic vessels present. About 3 stigmata in a mesh. Tentacles 28 in young and 40 in large specimen including minute ones. Ciliated groove U-shaped. Dorsal lamina a low plain membrane.

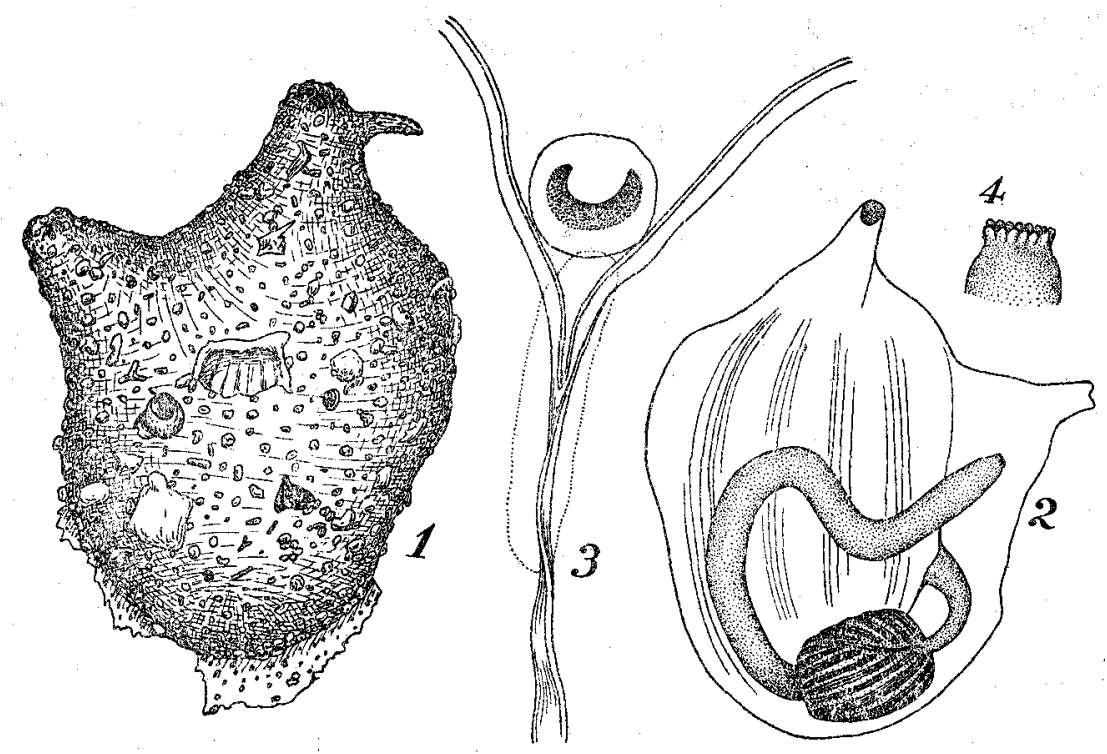

Fig. 20. Polyenrpa longicarpa n. sp. Young individual. 1-Entire animal from right side, 2-Left half of mancle body from outside, 3-Dorsal tubercle $\times 45,4-$ Anus.

Alimentary system: The second intestinal loop is formed evidently, although it is very shallow. The first loop very wide. Stomach globular and with 16 plications, though the plication is somewhat obscure in large specimen. Anus fringed with 13-20 lobules.

Gonad: Young specimen immature. About 20 elongate pinkish gonads on the right and 9 ones along the ventral margin of the left side. Large gonad with about a dozen testicular follicles on the side of attachment.

Remarks: The elongate shape of gonad is the most remarkable characteristic of the present new species. 


\section{Polycarpa quadrata HERDMAN 1881}

(Fig. 21)

Polyearpa quadrata; HERDMAN (1882): Rep. Voy. Challenger, Vol. 6, Tunicata, pp. 173-174, PI. 22, figs. 8-10.

TRAUSTEDT (1885): Vid. Meddel. fra naturh. Foren., ann., 1884, p. 48.

Styela quadrata; StuITER (1904): Siboga-Exped., Monogr. 56 a, p. 126.

Pandocia quadrata; VAN NAME (1918): U. S. Nat. Mus. Bull. 100, Vol. 1, Pt. 2, pp. 99-101, Figs. 50-52, Pl. 31, fig. 34 .

A very young individual, only $5 \mathrm{~mm}$ long excluding the posterior extension of the test, was found attached on the colony of Polycitor renzi-wadai. Body oval in outline, strongly compressed laterally and attached by the left side. Test thin, translucent, with some sand grains on the surface and sprinkled with pale purplish brown colour spots near the anterior end of the body. Both apertures terminal and 4-lobed. Siphons quite obscure. Mantle extremely thin, reddish orange to reddish brown in colour. Several endocarps on the inner surface.
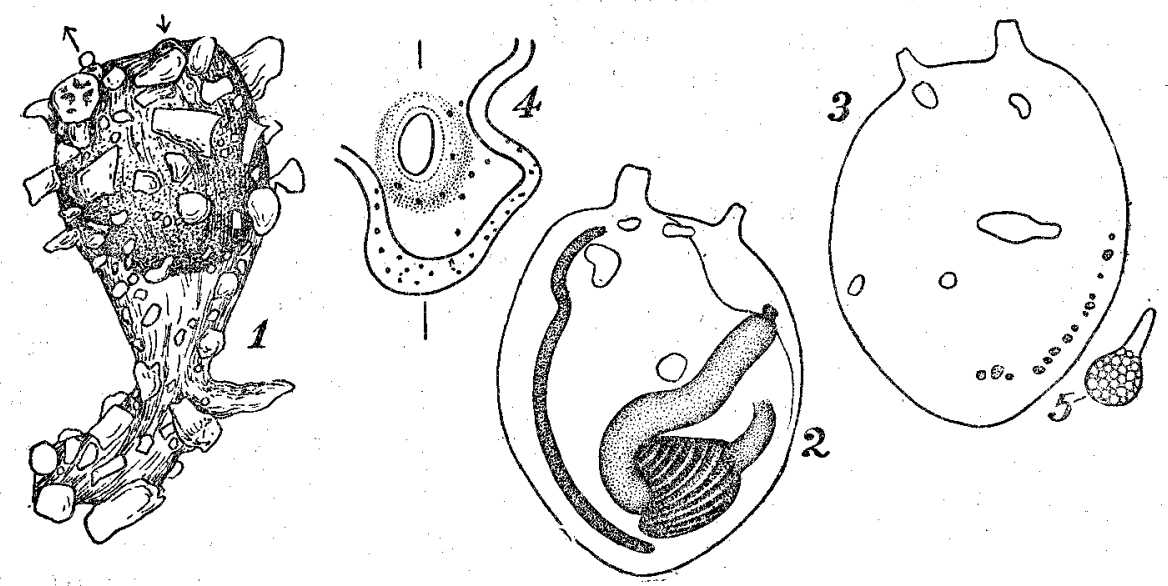

Fig. 21. Polycarpa quadrata HERDMAN. Young individual. 1-Entire animal from. right side, 2 -Left half of mantle body from outside, 3-Right half of mantle body from outside, 4-Ciliated groove $\times 110,5$-An immature gonad.

Branchial sac: Folds are not yet fully formed. Inner longitudinal vessels arranged as follows:
Left
D.
4
0
0
(5-6) $3 \quad \mathrm{~V}$.
Right
D. 3
(7) 0
(5) 0
(6) 0
(6) 2 V.

Transverse vessels and parastigmatic vessels alternate regularly. Stigmata rows only 12. Two elongate stigmata in a mesh. Tentacles 12 in total, ciliat- 
ed groove an oval opening, dorsal lamina a plain membrane: Many small pigment spots sprinkled around the porsal tubercle.

Alimeniary system: Loop simple. Rectum nearly straight, with a slight bending near the middle of its course. Stomach globular, with ca. 12 plications on each side. Margin of anus thickened, lobation quite obscure.

Gonad: Fourteen immature gonads are arranged in a row along the postero ventral margin on the right side. None on the left side.

Remarks: I refer to the present specimen with some doubts. It is however, very probable that the present specimen represents a young individual of $P$. quadrata, since the appearance of the alimentary canal, the simple figure of ciliated groove and the arrangement of gonads in a row along the posteroventral side in the former quite coincide with those in the latter.

\section{Polycarpa aurita (SLUITER) 1890}

(Fig. 22)

Styela aurita; SLUITER (1890): Natuurk. Tijdschr. Ned.-Ind., L, pp. 338-340, Pl. 2, fig. 12. SI UIT FR (1904): Siboga-Exped., Monogr. 56 a, p. 59.

Polycarpa aurita; SrUITIER (1919): Bijd. Dierk, Afl, XXI, p. 3.

Hartmeyer (1919) : Kungl. Sv. Vetensk. Handl., Bd. 60, No. 4, pp. 81-86, P1. 2, figs. $43-47$.

HAstings (1931): Great Barrier Reef Exped., Vol. IV, No. 3, pp. 75-76, Fig. 2.

Two specimens were collecfed by Mr. R. WADA. The larger one is 61 $\mathrm{mm}$ long $\times 40 \mathrm{~mm}$ wide and with $37 \mathrm{~mm}$ height, while the smaller one is $30 \mathrm{~mm}$ in length. Body oval, attached to the substratum by the postero-ventral side. Branchial aperture terminal, atrial aperture slightly in front of the middle of the body and slightly displaced to the right side from the dorso-median line. Both apertures 4-lobed. Siphons indistinct. Test whitish yellow to grayish yellow, ca. $2 \mathrm{~mm}$ in thickness, leathery and very tough and strong, with many grooves and folds on the surface, especially in the antero-dextral part of the body. Sponges, Bryozoans etc. are adhered on the surface. Inner surface of the test white. Mantle very thick, reaching $3 \mathrm{~mm}$ in some places, yellow-yellowish gray in colour and somewhat darkly coloured around the apertures. Many blood vessels are issued outwards from the outer surface of the mantle. Many large endocarps present. Those along the ventral margin and along the alimentary canal are very large, reaching ca. $9 \mathrm{~mm}$ in length. Extremely delicate atrial tentacles on the margin of the atrial velum.

Branchial sac: Inner longitudinal vessels arranged as follows :

$61 \mathrm{~mm}$ long individual : 


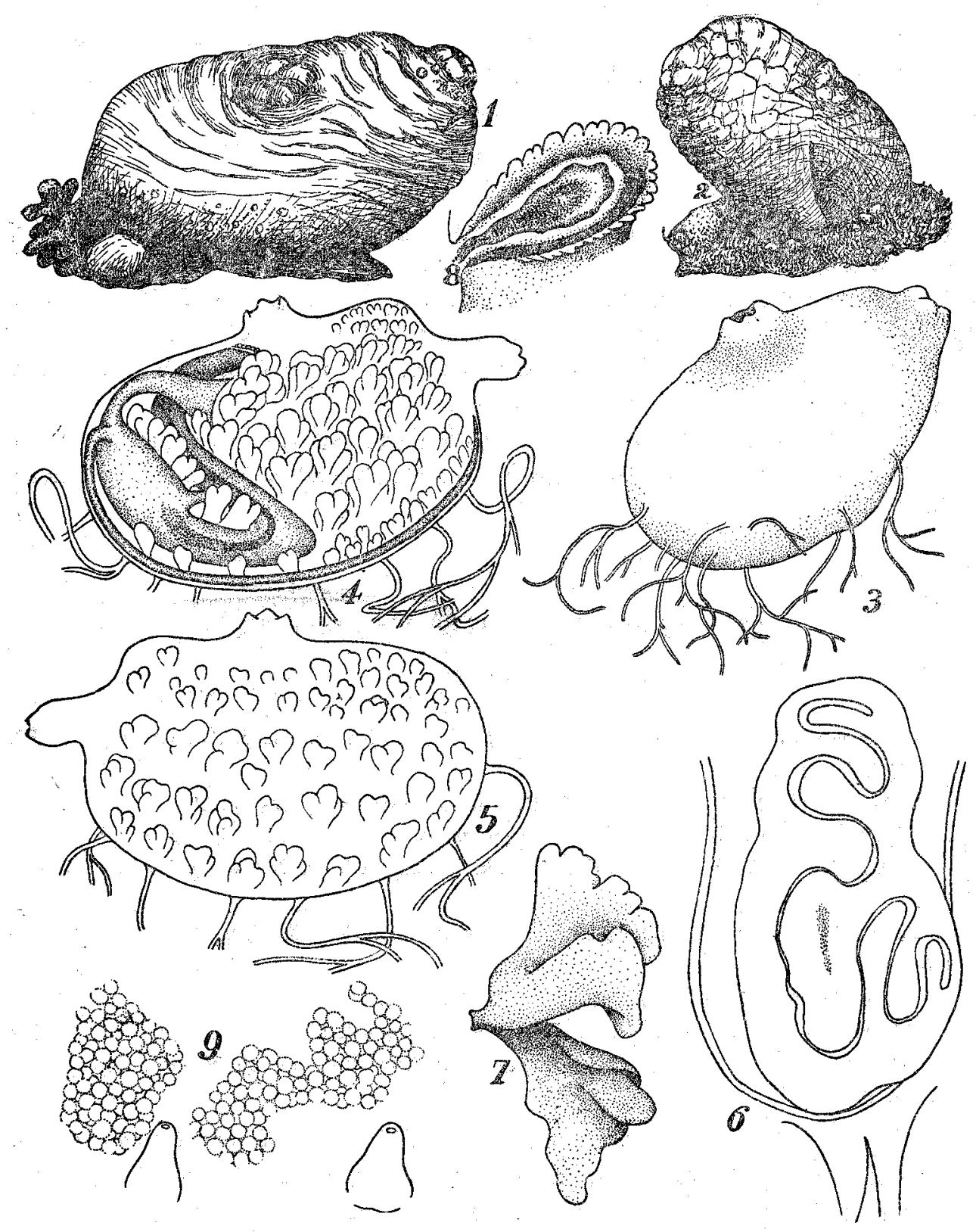

Fig. 22. Polycarpa aurita (StUTER). 1-51 $\mathrm{mm}$ long individual, 2-30 mm long individual, 3-Mantle body from right side, 4-Left half from inside, 5-Right half from inside, 6Dorsal tubercle $\times 12,7-$ A large endocarp, 8-Anus, 9-A pari of mantle, showing two genital apertures $\times 45$. 


$\begin{array}{llllllllllll}\text { Left } & \text { D. } & 5 & (30) & 6 & (36) & 8 & (40) & 8 & (45) & 8 & \text { V. } \\ \text { Right } & \text { D. } & 6 & (27) & 8 & (50) & 10 & (60-70) & 10 & (50) & 8 & \text { V. } \\ \text { mm long individual: } & & & & & & & & \\ \text { Left } & \text { D. } & 5 & (40) & 6 & (31) & 7 & (27) & 5 & (22) & 4 & \text { V. } \\ \text { Right } & \text { D. } & 5 & (39) & 5 & (32) & 7 & (28) & 7 & (25) & 3 & \text { V. }\end{array}$

Three to seven thinner transverse vessels between each pair of thicker ones. Parastigmatic vessels present. Four to six stigmata in a mesh. Tentacles 1828 , large and small ones alternate rather regularly. Dorsal tubercle very large, $4.5 \mathrm{~mm}$ in length in $61 \mathrm{~mm}$ long individual. Ciliated groove U-shaped, with horns complexly undulating. Dorsal lamina a tall plain membrane.

Alimentary system: Stomach without plication, not much thicker than the following intestine. Anus finely lobed.

Gonad: Completely burried in the mantle, merely apertures being observable on the surface. They seem to be distributed rather evenly on both sides.

\section{Microcosmus helleri HERDMAN 1881}

(Fig. 23)

Mierocosmus helleri; HERDMAN (1882): Rep. Voy. Challenger, Vol. 6, Tunicata, pp. 131-132, Pl. XIV, figs. 1-4.

TRAUSTENT (1885): Vid. Meddel. fra natu:h. Foren., ann. 1884, p. 41.

SLUiTER (1895): Semon Zoolog. Forschungsreisen, V. p. 184, PI. X, figs. 8 \& 9.

HARTMEYer (1919): Kungl. Sv. Vetensk. Handi., Bd. 60, No. 4, pp. 19-26, Pl. I, figs. 6-9.

VAn Name (1921): Bull. American Mus. Nat. Hist., Vol. XLIV, pp. 463-466, Figs. 145146.

VAN NAME \{1924): Bijd. Dierk., Af. XXIII, p. 31.

HAstiNGs (1931): Great Barrier Reef Exped., Vol. IV, No. 3, p. 72.

VAN NAME (1945): Bull. American Mus. Nat. Hist., Vol. 84, pp. 349-351, Fig. 232, Pl. 10 , fig. 5 .

Two specimens were collected by Mr. S. WADA. The larger one is $70 \mathrm{~mm}$ long and the smaller one is $35 \mathrm{~mm}$ in length. Body oval in shape. The larger specimen attached to the substratum by its right posterior part of the body and seems to be lying with its right side beneath, while the smaller one attached by the posterior end of the body. Branchial aperture terminal, atrial aperture about the middle of the body or situated more posteriorly. Each aperture on a low prominence and 4-lobed. Test leathery and rather thin, about $1 \mathrm{~mm}$ in thickness, but very strong and tough and pinkish brown to 


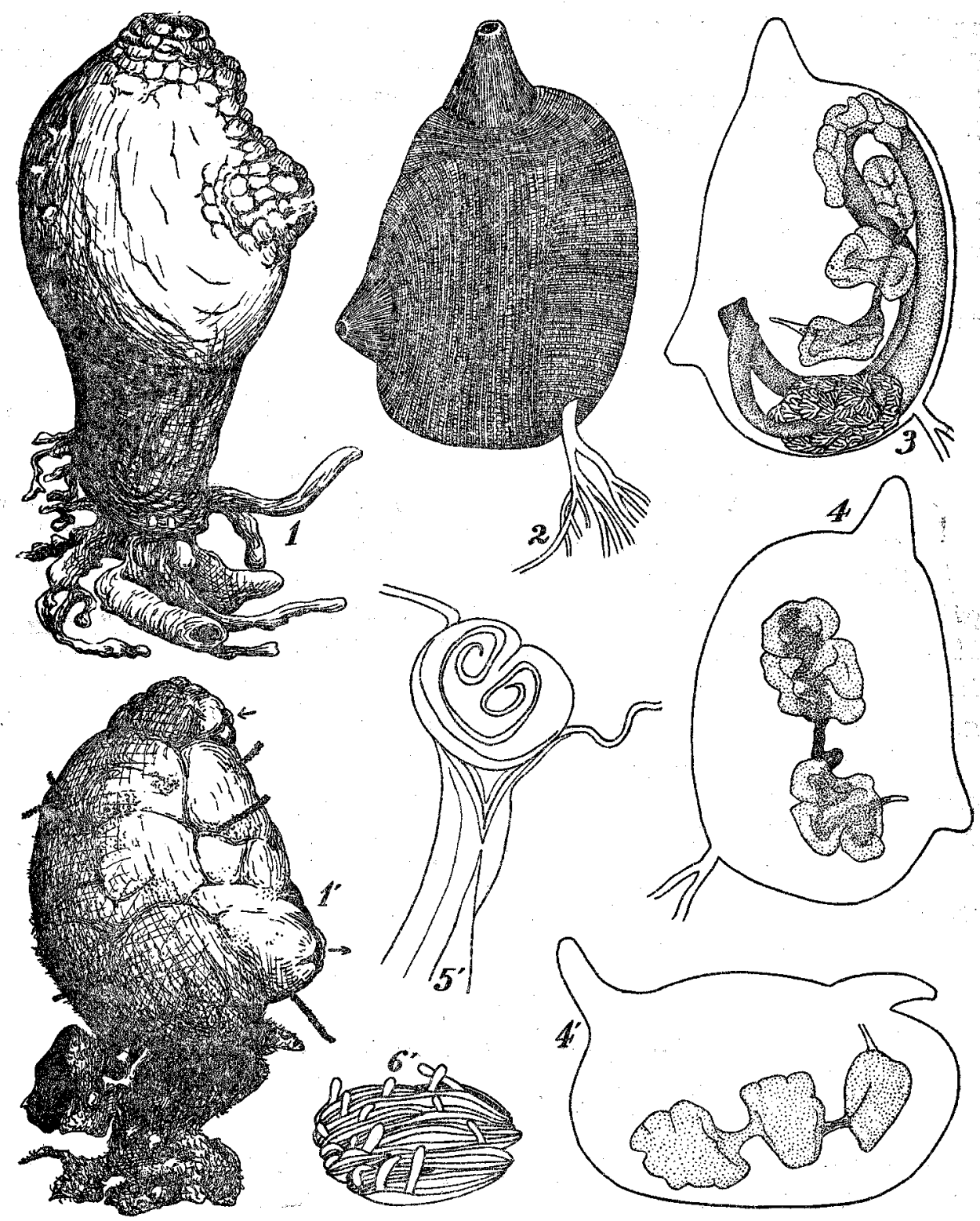

Fig. 23. Microeosmus helleri HERDMAN. 1-4: $70 \mathrm{~mm}$ long individual; 1': 4'-6':35 mm long individual. 1-Entire animal from left side, 2-Mantle body from right side, 3-Left half from inside, 4-Right half from inside, 5-Dorsal tubercle $\times 12$, 6-A part of liver, magnified.

grayish brown in colour. It is wrinkled irregularly around the apertures and in the posterior part of the body, while the other part is rather smooth ex- 
cepting a few faint grooves. The inner surface of test pale pinkish brown. Some hydrozoans, didemnids etc. are found on the surface. Mantle reddish brown in colour and not thick. Muscular bands arranged very regularly: Iongitudinal bands outside the transverse ones on the dorsal half of the body, while the arrangement of muscular bands is entirely reversal on the ventral half. On the mantle body, the atrial siphon is placed near the posterior end of the body.

Branchial sac: Six folds on each side. Inner longitudinal vessels arranged as follows:

$70 \mathrm{~mm}$ long individual :

$\begin{array}{llllllllllllllll}\text { Left } & \text { D. } & 5 & (25) & 7 & (19) & 6 & (20) & 6 & (15) & 5 & (13) & 4 & (8) & 2 & \text { V. } \\ \text { Right } & \text { D. } & 5 & (21) & 6 & (18) & 6 & (20) & 5 & (19) & 6 & (14) & 5 & (9) & 3 & \text { V. }\end{array}$

$35 \mathrm{~mm}$ long individual :

$\begin{array}{llllllllllllllll}\text { Left } & \text { D. } & 5 & (27) & 5 & (23) & 5 & (20) & 6 & (16) & 5 & (13) & 4 & (10) & 2 & \text { V. } \\ \text { Right } & \text { D. } & 5 & (25) & 5 & (20) & 5 & (22) & 5 & (21) & 4 & (17) & 5 & (15) & 2 & \text { V. }\end{array}$

Seven to fifteen thinner transverse vessels, classified roughly in three orders, between each pair of thicker ones. Parastigmatic vessels present. Five to seven stigmata in a mesh. Tentacles 14-15 excluding minute ones, large and small ones alternate regularly; branches in two orders. Ciliated groove U-shaped, with its horns strongly curled in.

Alimentary system: Intestinal loop long and narrow. Several small endocarps found on the bending part of intestine. Liver forms a compact group. Anus plainly margined.

Gonad: The right gonad consists of two-three capsules, while the left gonad of three capsules.

\section{Microcosmus propinquus HERDMAN 1881}

(Fig. 24 and Fig. 25-5')

Mierocosmus propinquus; HERDMAN (1882): Rep. Voy. Challenger, Vol. VI, Tunicata, pp. 132-133, Pl. XIV, figs. 5 \& 6 .

TraustedT (1885): Vid. Meddel. fra naturh. Foren., ann. 1884, p. 42.

St.UrTer (1904): Siboga Exped., Monogr. 56 a, p. 51.

Seven specimens collected by Mr. S. WADA were at my disposal. The largest one is $22 \mathrm{~mm}$ in length, while the smallest one only $8 \mathrm{~mm}$ long. Body roughly oval, with short branchial siphon at terminal and atrial siphon of about the same length nearly at the middle of the body. It is attached by its right ventral or right postero-ventral side of the body. Test leathery and 


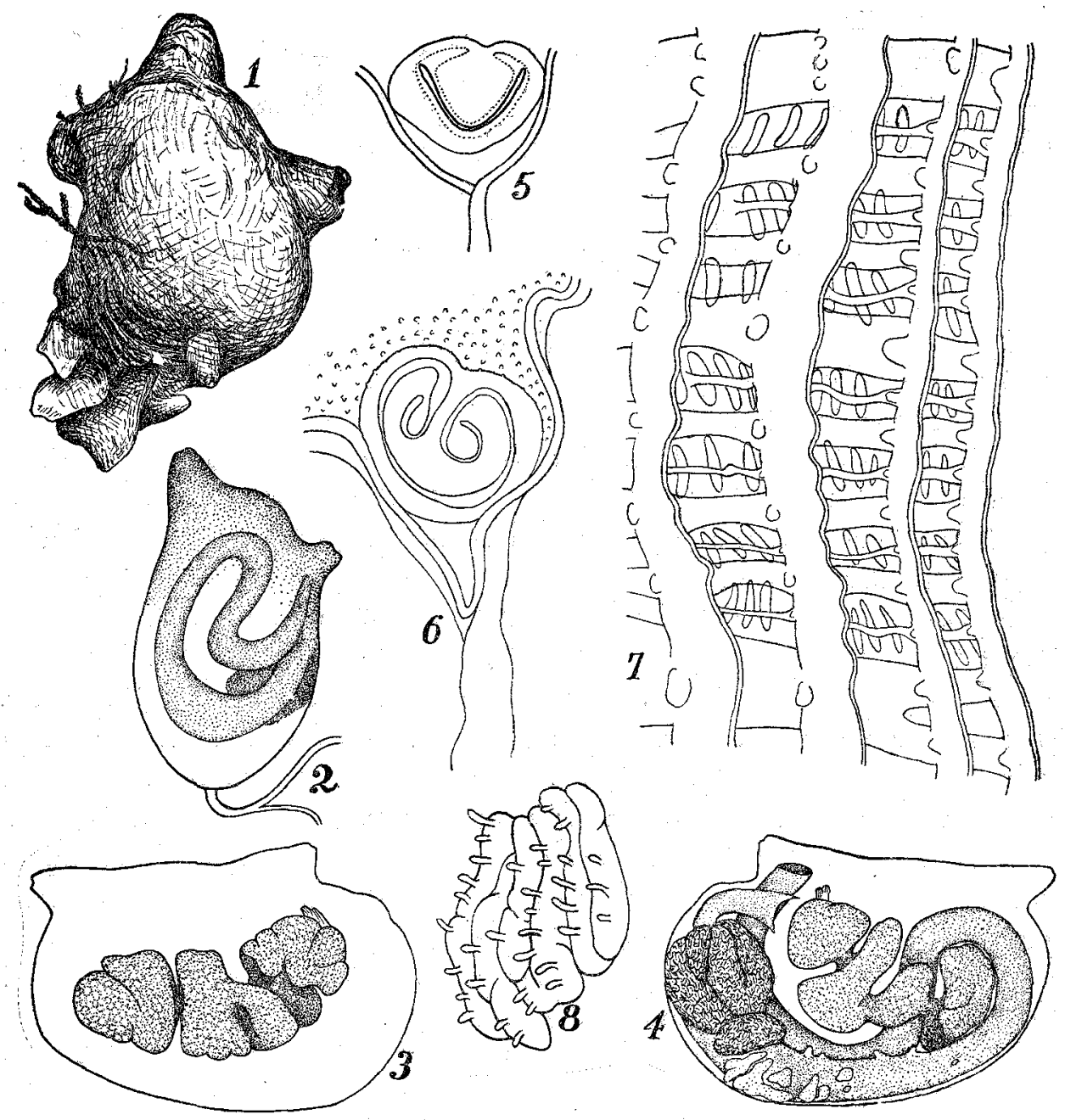

Fig. 24. Microcosmus propincuis HeRDMAN. 1-Entire animal from left side, 2-Mantle body of a small individual from left side, 3-Right half from inside, 4-Left half from inside, 5-Dorsal tubercle of a small individual $\times 45$, 6-Dorsal tubercle of a large individual $\times 28,7-\mathrm{A}$ part of branchial sac $\times 45,8-\mathrm{A}$ part of liver, magnified.

rather thick, reddish brown in colour and with some foreign matters adhered on the surface. Surface nearly smooth excepting a few slight wrinkles on larger individuals. Inner surface of test pearly white or grayish white. Mantle reddish brown to brick red in colour and considerably thick, muscular bands arranged very regularly. Atrial tentacles present. Many spinules ica. $60 \mu$ long) on the inner surface of siphons (Fig. 25-5').

Branchial sac: Six to eight folds are present. Inner longitudinal vessels 
arranged as follows:

$22 \mathrm{~mm}$ long individual :

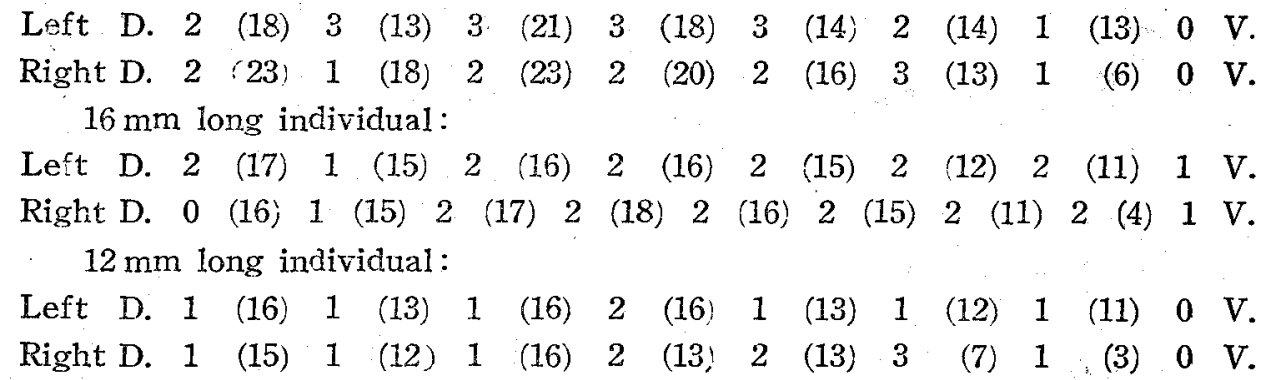

$8 \mathrm{~mm}$ long individual:

$\begin{array}{lllllllllllllllll}\text { Left D. } & 1 & \text { (13) } & 1 & \text { (8) } & 1 & \text { (15) } & 1 & \text { (15) } & 1 & \text { (10) } & 1 & \text { (8) } & 1 & \text { (5) } & 1 & \text { V. }\end{array}$

Right D. 1 (17) 1 (8) 1 (13) 1 (12) 1 (11) 1 (8) 0 V.

$10 \mathrm{~mm}$ long individual (Body proper $6 \mathrm{~mm}$ long, peduncular extension of test $4 \mathrm{~mm}$ ):

$\begin{array}{llllllllllllllll}\text { Left } & \text { D. } & 0 & (13) & 0 & \text { (5) } & 1 & \text { (11) } & 1 & \text { (9) } & 0 & \text { (8) } & 0 & \text { (1) } & 0 & \text { V. }\end{array}$

Right D. 0 (12) 0 (5) 1 (10) 1 (11) 1 (10) 1 (8) 1 V.

Ábout 3 thinner transverse vessels between each pair of thicker ones. Parastigmatic vessels present. Three stigmata in a mesh. Tentacles ca. 35 excluding minute ones, branches in 2 orders. Ciliated groove U-shaped, with anterior horns strongly incurled in large individuals. Prebranchial area papillated. Many small papillae on inner longitudinal vessels in some individuals. Besides, many papillae are found along the left side of endostyle, especially remarkably in smaller individuals.

Alimentary system: Liver yellowish brown. Some small endocarps on intestine behind the liver. Anus plainly margined.

Gonad: Three-four genital capsules on the right and four to five ones on the left side.

\section{Microcosmus exasperatus HELLER 1878}

(Fig. 25)

Microcosmus variegatus; TRAUSTEDT (1885): Vid. Meddel. fra naturh. Foren., Foren, ann. 1834, pp. $42-43$.

Mierocosmus miniatus; VAN NAME (1902): Trans. Connecticut Acad. Sci., Vol. 11, pp. 396397, PI. 56, fig. 79; Pl. 57, figs. 91-95; Pl. 62, figs. 129-180; Pl. 64, fig. 148.

Mierocosmus exasperatus; VAN NAME (1918): U. S. Nat. Mus. Bull. 100, Vol. 1, Pt. 2, pp. 81-83, Figs. 30-32, Pl. 32, flg. 29. 


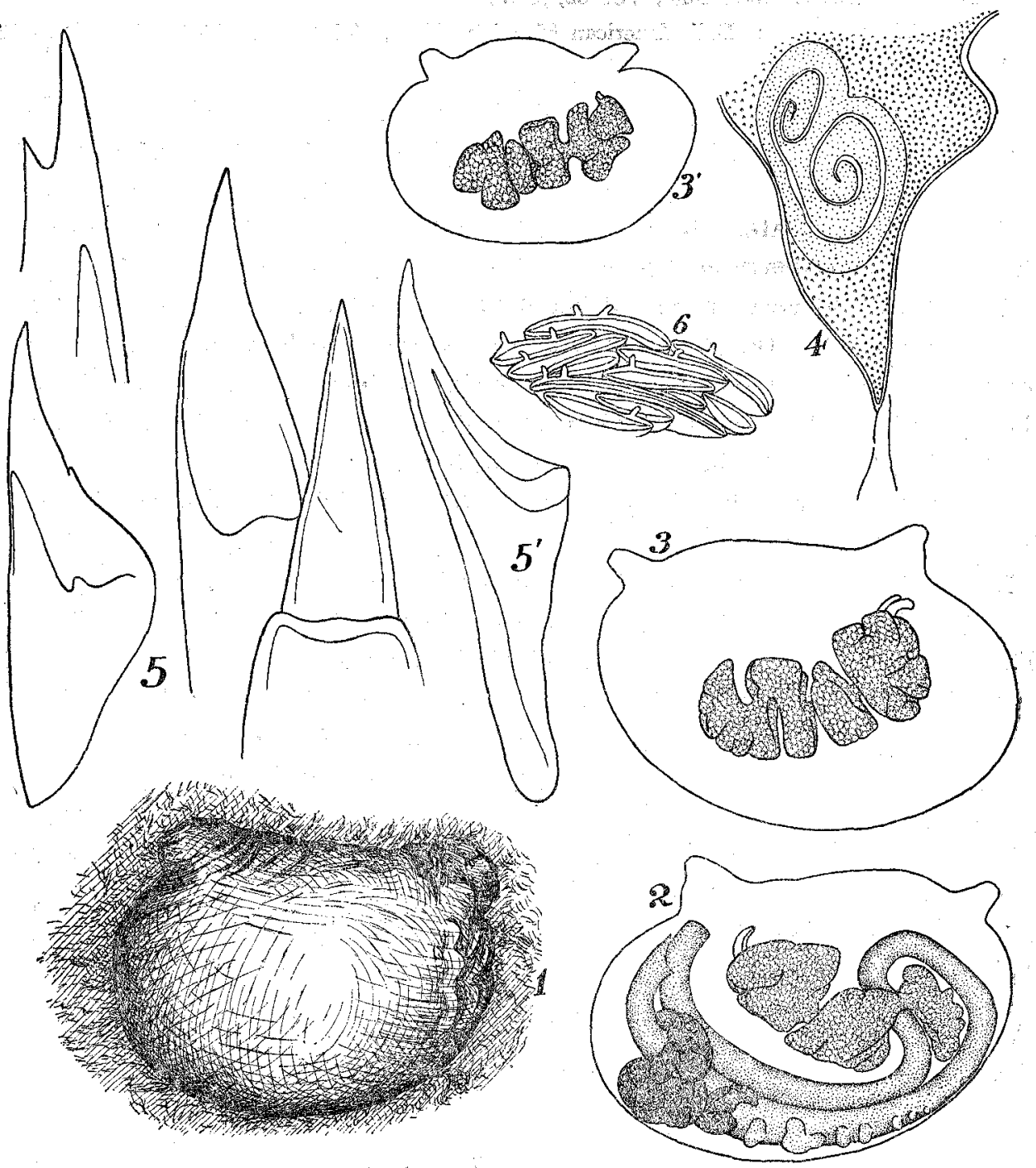

Fig. 25 Microcosmus exaspsratus HELLER, except 5 which shows a spinule $(\times 1200)$ from the inner surface of siphons in Microcosmus propinquus HERDM. 1-Entire animal from teft side, 2-Left half of $32 \mathrm{~mm}$ long individual from inside, 3-Right half of the same from inside, 3-Right half of $19 \mathrm{~mm}$ long invidual from inside, 4-Dorsal tubercle $\times 12,5-$ Spinules faom the inner surface of siphons $\times 200,6-\mathrm{A}$ part of liver, masnified.

VAN NAME (1921) : Bull. American Mus. Nat. Hist., Vol. XLIV, pp. 459-462, Figs. 137144.

VAN NAME (1924): Bijd. Dierk, Af. XXIII, p. 31. 
BERRIJI. (1932): Biol. Bull., Vol. 62, p. 78.

VAN NAME (1945): Bull. American Mus. Nat. Hist, Vol. 84, pp. 346-349, Figs. 230-231, Pl. 16, fig. 3.

Three specimens collected by Mr. R. WADA. The largest one $32 \mathrm{~mm}$ and the smaller ones $19 \mathrm{~mm}$ in length. Body oval, attached to the shell surface by its whole right side or right ventral side. Branchial aperture subterminal, atrial aperture situated about $1 / 3$ the body length from the posterior end of the body. Both apertures 4-lobed and opened each on a short siphon. Test red, lerthery and very strong, although it is not thick. Inner surface of test pearly white. Mantle is not thick and grayish yellow to pale yellowish orange, muscular bands arranged regularly to form a neat cross stripes on the dorsal half. Minute atrial tentacles are present. Many spinules (less than $300 \mu$ in length) on the inner surface of siphons.

Branchial sac: Nine folds on the right and eight folds on the left side. Inner longitudinal vessels arranged as follows in $32 \mathrm{~mm}$ long individual.

$$
\text { Left D. } 5 \text { (22) } 4 \text { (21) } 5 \text { (25) } 5 \text { (24) } 5 \text { (25) } 5 \text { (24) } 4 \text { (18) } 2 \text { (12) } 0 \mathrm{~V} \text {. }
$$

Right D. 2 (24) 5 (24) 4 (26) 4 (27) 4 (27) 5 (25) 4 (21) 4 (19) 1 (11) 0 V. Three to seven thinner transverse vessels between each pair of thickner ones. Parastigmatic vessels present. Many prominent papillae along the transverse vessels on the outer surface of the branchial sac. Four to six stigmata in a mesh. Tentacles 16, large and small ones alternate regularly, branches in two orders. Ciliated groove horse-shoe-shaped, opening towards the left side and with its horns strongly curled in. Edge of dorsal lamina plain. Prebranchial area and also the dorsal tubercle are papillated.

Alimentary system: Several small endocarps behind the liver which is dark brownish in colour. Margin of anus plain.

Gonad: Three capsules on the left and $4-5$ ones on the right side.

\section{Microcosmus multiplicatus n. sp.}

(Fig, 26)

A $47 \mathrm{~mm}$ long specimen was found by Mr. S. WADA. Body nearly globular, with siphons bending towards the right side which is somewhat flattened and covered with very thin test. The left side of the body is covered with didemnids, bryozoans and hydrozoans etc. The animal seems to be lying with its right side beneath. Branchial aperture terminal, atrial aperture at the middle of the body. Both apertures 4-lobed and each on a low prominence. 
Test leathery, thin, but very strong and reddish brown in colour, with some pearly glistening on the inner surface. Mantle fleshy in colour, muscular bands form a cross stripes on the dorsal half. Delicate atrial tentacies are present. Spinules, less than $350 \mu$ in length, are found on the inner surface of siphons.

Branchial sac: Eleven folds on the right and twelve ones on the left side. Inner longitudinal vessels arranged as:
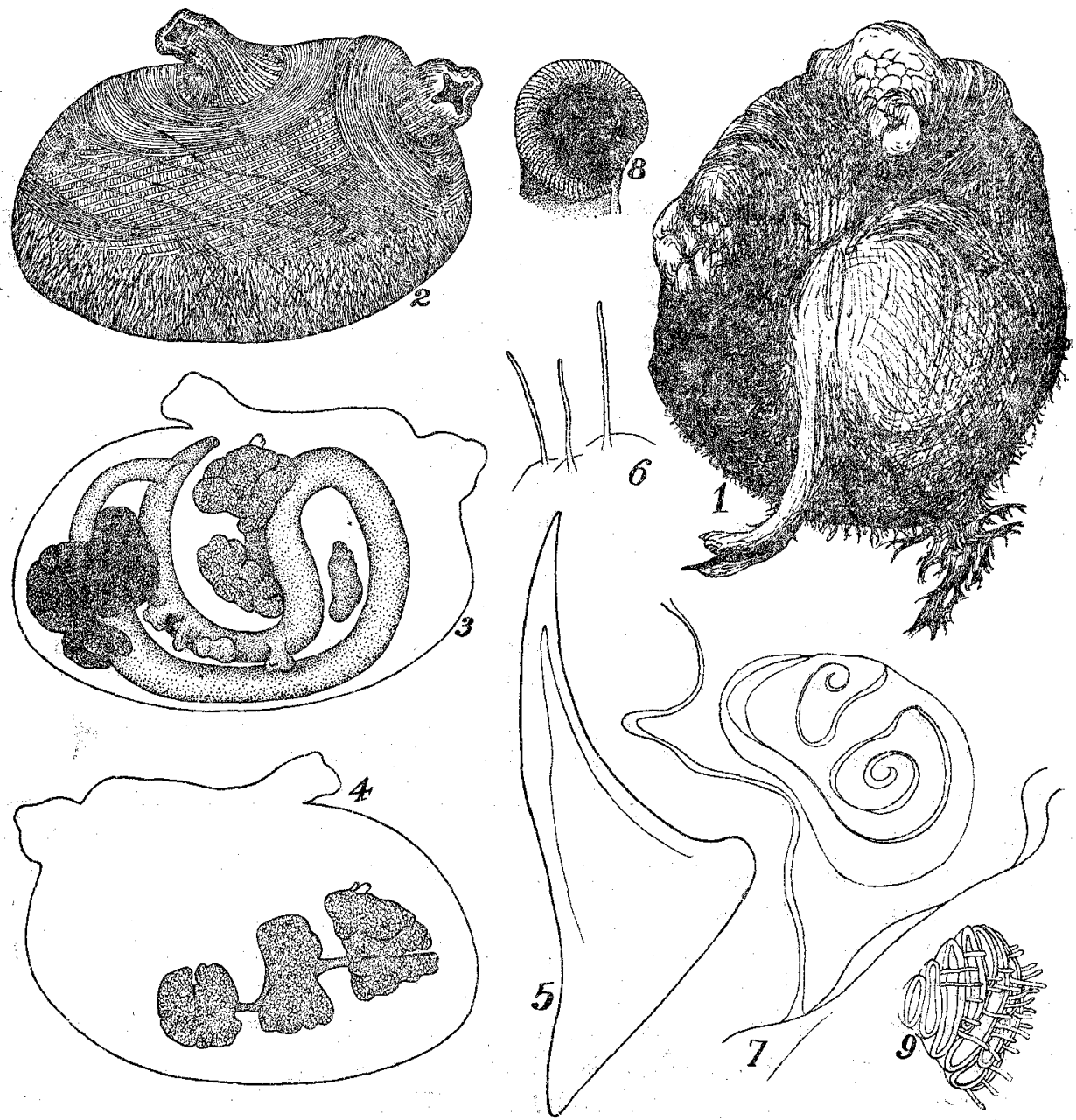

Fig. 26. Microcosmus multiplicatus n. sp. 1-Entire animal from right side, 2-Mantle"body from tight side, $3-$ Left balf from inside, 4-Right half from inside, 5-A spinule from the inner surface of siphons $\times 200,6$-Atrial tentacles $\times 45,7 \rightarrow$ Dorsal tubercle $\times 12,8$-Anus, 9-A part of liver $\times 12$. 


$\begin{array}{lccccccccccccccc}\text { Left } & \text { D. } & 5 & (20) & 5 & (28) & 8 & (26) & 7 & (28) & 7 & (28) & 7 & (24) & 6 & (22) \\ & & & & 6 & (18) & 7 & (16) & 4 & (13) & 3 & (8) & 2 & (4) & 2+\mathrm{V} . \\ \text { Right } & \text { D. } & 5 & (23) & 5 & (28) & 5 & (28) & 7 & (28) & 8 & (27) & 8 & (27) & 6 & (21 \\ & & 6 & (17) & 6 & (14) & 3 & (13) & 3 & (5) & 1 & \text { V. } & & & \end{array}$

Three to seven transverse vessels between each pair of thicker ones. Parastigmatic vessels present. About 6 stigmata in a mesh. Tentacles 21 excluding minute ones, large and small ones alternate regularly, branches in 3 orders. Pretentacular area papillated. Dorsal tubercle rosette-formed. Edge of dorsal lamina plain.

Alimentary sysiem: Several small endocarps at the bending portion of the second intestinal loop. Anus finely lobed.

Gonad: Three genital capsules on each side.

Remarks: The present specimen is possibly a form of $M$. exasperatus, which is provided with too numerous branchial folds for this species. For the present, however, it seems to be convenient for recording materials to give a new name to the present specimen provisionally.

\section{Pyura vittata (STIMPSON) 1852}

(Fig. 27)

Halocynthia rubrilabia+Halocynthia riissana var. munia; VAN NAMF (1902): Trans. Connecticut Acad. Art. Sci., Vol. XI, pp. 393-395, Pl. 56, figs. 83 \& 84; Pl. 57, figs. $85-87$ \& 90; PI. 62, fig. 133; Pl. 63, fig. 141; PI. 64, figs. $150 \& 152$.

Falocynthia karasboja; OKA \{1906): Annot. Zool. Japon., Vol. VI, Pt. 1, pp. 48-49.

Pyura vittata; VAN NAME (1921): Bull. American Mus. Nat. Hist., Vol. XLIV, pp. 446451, Figs. 112-122.

VAN NAME (1924): Bijd Dierk., Afl. XXII, p. 31.

BERRILI. (1932): Biol. Bull., Vol. 62, p. 78

VAN NAMre (1945): Bull. American Mus. Nat. Hist., Vol. 84, pp. 321-335, Figs. 213-215, Pl. 16, fig. 5 .

PgR:S (1949): Bull. l'Inst. franç. Afrique noire, Tom. XI, p. 195.

TokroKa (1949): Publ. Seto Mar. Biol. Lab., I (2), p. 59, Fig. 13.

Tokioka (1950): Publ. Seto Mar. Biol. Lab., I (3) pp. 146-147, Fig. 21.

Cynthia vittata; OKA (1935\}: Sci. Rep. Töhoku Imp. Univ., 4th Ser., Vol. X, pp. 439-440, Figs. $8 \& 9$.

A small $13 \mathrm{~mm}$ long individual was found in the colony of Stolonica (Amphicarpa) sigma. Body oval, with apertures at the dorsal side. Each apertures 4-lobed and marked with 4 dark greenish striations converging to the aper- 


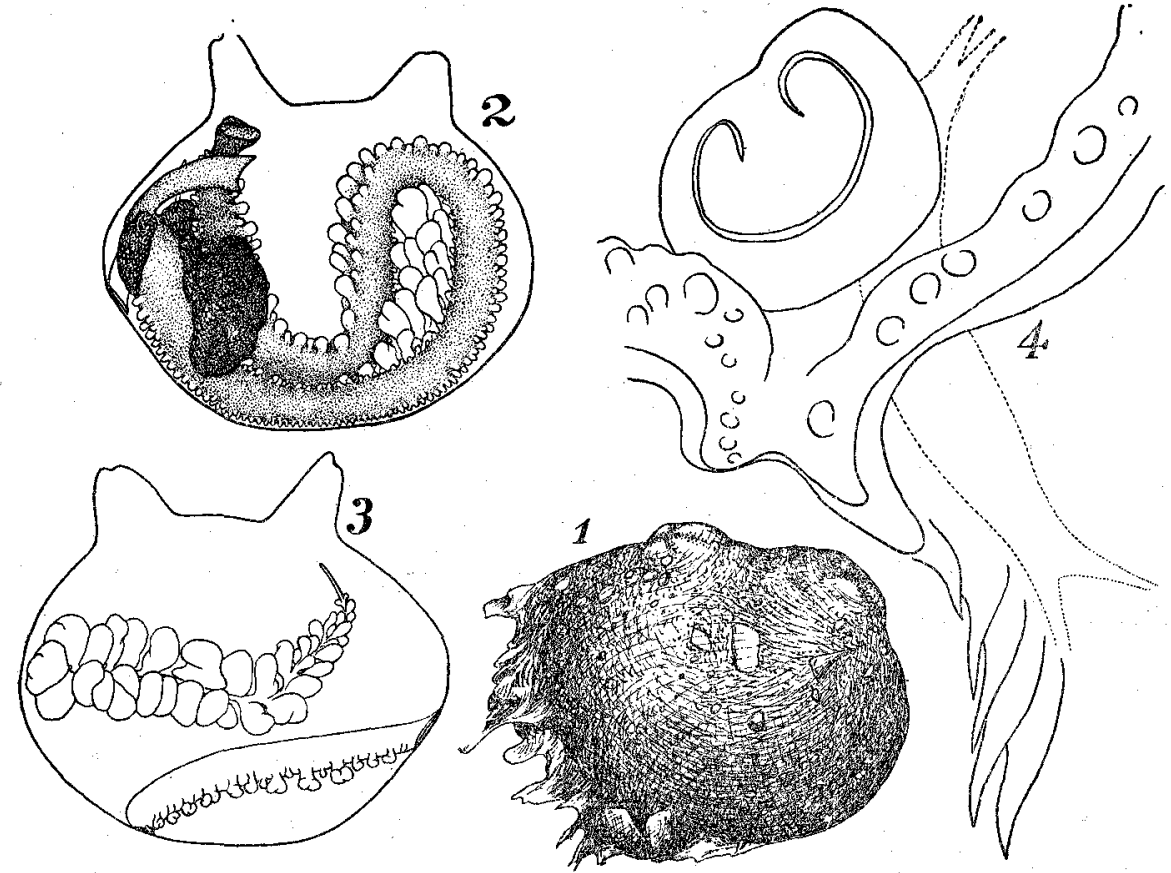

Fig. 27. Pyura vittata (STIMPSON). 1-Entire animal from right side, 2-Left half from inside, 3-Right half from inside, 4-Dorsal tubercle and dorsal languets $\times 45$.

tures. Test yellowish white, leathery, of moderate thickness and with some foreign matters on the surface. Mantle thin, translucent and salmon in colour. Atrial velum well developed.

Branchial sac with 6 folds on each side. Inner longitudinal vessels arranged as :
Left
D. 3
(14) 4
(15) 3
(16)
(16) 4
(15) 4
(12) $4 \mathrm{~V}$.
Right D. 5
(15) 4 (16) 4
(18) 4 (18) 4
17) 3
(13) $3 \mathrm{~V}$.

Three to seven thinner transverse vessels between each pair of thicker ones. Parastigmatic vessels present. About 3 stigmata in a mesh. Tentacles 16, arranged-large-small-medium-small-large-, branches in 2 orders. Ciliated groove U-shaped, with anterior horns slightly incurled. Anus plainly margined. Gonad immature. 


\section{Pyura el ongata n. $\mathrm{sp}$.}

(Fig. 28)

One specimen was found by Mr. R. WADA. It is $24 \mathrm{~mm}$ long $\times 15 \mathrm{~mm}$ wide with $9 \mathrm{~mm}$ height. Body elongate oval and attached by whole ventral side. Branchial aperture terminal, atrial aperture subterminal near the opposite side of the branchial. Both apertures 4-lobed and marked with orange colour. Test yellowish white in colour and wrinkled irregularly. It is much thicker on the dorsal side than on the ventral side. Mantle grayish yellow and of moderate thickness. Muscular bands arranged regularly to form a fine cross stripes on the dorsal side. Atrial velum well developed. Minute spinules on the inner surface of the distal part of the branchial siphon.

Branchial sac: Six folds on each side. Inner longitudinal vessels arranged as follnws:

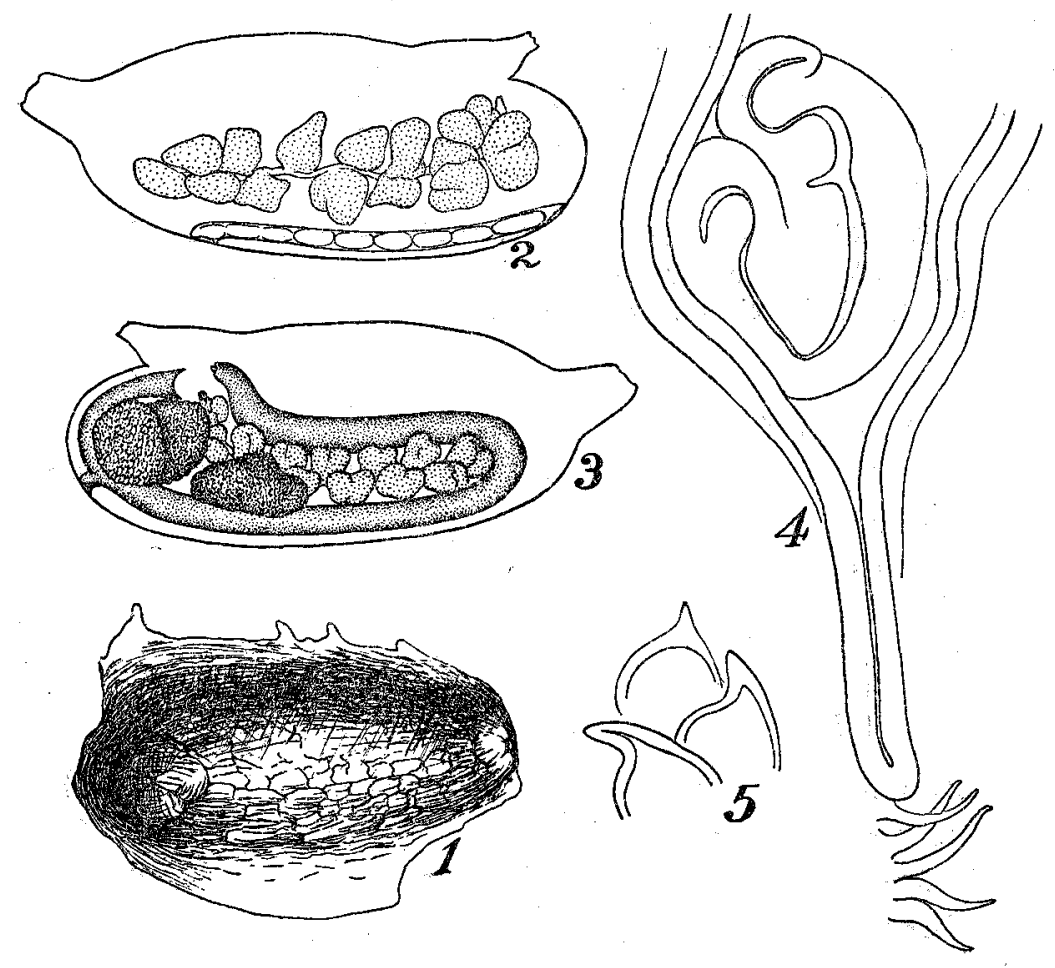

Fig. 28. Pyura clongata n. sp. 1-Entire animal from dorsal side, 2-Right haif from inside, 3-Left half from inside, 4-Dorsal tubercle $\times 45,5$-Spinules from the inner surface of the branchial siphon $\times 1200$. 

Left
D. 0
(20) 2
(23)
(24)
(24) 3
(18) 4
(13) $5 \mathrm{~V}$
Righ.t
D. 0
(17) 2
(23) 2
(24) 2
(27) 3
(22) 2
(17) $5 \mathrm{~V}$.

Three to seven thinner transverse vessels between each pair of thicker ones. Parastigmatic vessels present. Two-three stigmata in a mesh. Tentacles 37 in all, branches in 2 orders. Ciliated groove U-shaped.

Alimentary system: Intestinal loop of a uniform width. Each branch of the loop runs parallel to each other. Liver yellow-yellowish white in colour and divided into anterior and posterior groups, the former of which consisting of two lobes. Margin of anus plain.

Gonad: As in common pyurids.

Remarks: At a glance this new species resembles closely $P$. mirabilis ( $v$. Drasche), $P$. subuculata (Siditer) and $P$ shiinoi ToKIoKa in the appearance of the alimentary canal and liver, but differs distinctly from these species in having 6 branchial folds instead of 7 and tentacles with branches in 2 orders.

\section{Herdmania momus (SAVIGNY) 1816}

(Fig. 29)

Cynthia pallida; HERDMAN (1882): Rep. Voy. Challenger, Vol. VI, Tunicala, p. 143, Pl. XVII, figs. 17-21.

TRAUSTEDT (1885): Vidensk. Meddel. fra naturh. Foren., ann. 1884, p. 35.

Cynthia pallida+O. pallida var. billitonensis; HERDMAN (1886): Rep. Voy. Cha!lenger, Vol. XIV, Tunicata, App. A., pp. 405-405.

Cynthia pallida var. billitomensis; SLUITER (1890): Natuurk. Tijdschr. Ned.-Ind., Vol. 50, p. 331.

Rhabdocynthia pallida; SLUITER (1897): Zool. Jahrb., Syst., Vol. 11, p. 7.

SLUITER (1904): Siboga-Exped., Monogr. 56 a, pp. 54-55.

HERDMAN (1906): Ceylon Pearl Oyster Fish., Suppl. Rep., No. 39, p. 308, PI. 2, figs. 36-39.

Halocynthia pallida; HARTMEYER (1905) : Zool. Jahrb., Syst. Suppl., Bd. 8, p. 384.

Michaelsen (1905): Zool. Jahrb., Syst. Suppl., Bd. 8, pp. 78-85, Taf. 4 fig. 11.

HARTMEYER (1906): Zool. Anz,, Bd. 31, p. 4, Fig. 2.

Pyara pallida; HARTMEYeR (1911): Bronn. Tier-Reich., Bd. III, Suppl. p. 1340.

HARTMEYER (1912): Deutsche Tiefsee-Exped., Bd. 16, pp. 361-363.

Van Name \{1918;: U. S. Nat. Mus. Buil. 100, Vol 1, Pt. 2, pp. 76-79, Figs. 19-25, PI. 32 , figs. $36-38$.

Pynura momus var. pallida; M CHAELSEN \{1921\}: Ark. f. Zool., Bd. 13, No. 23, pp. 1-2.

Pyura (Rhabdocynthia) momus form pallida; VAN NAME (1921): Bull. American Mus. Nat. Hist., Vol. XLIV, pp. 454-459, Figs. 129-136. 
Herdmania momus; VAN NAME (1945): Bull. American Mus. Nat. Hist., Vol. 84, pp. 341344, Figs, $225 \& 226$.

ToKIOKA (1949) : Publ. Seto Mar. Biol. Lab., I \{2\}, pp. 61-62, Fig. 15, Pl. VIII, figs. 5 \& 6 .

TokiokA (1950): Publ. Seto Mar. Biol, Lab., I (3), p. 150, Fig. 23-5.

Rhabdocynthia ceylonica; HERDMAN (1906) : Ceylon Pearl Oyster Fish., Suppl. Rep, No. 39. Pyura pallida f. ceylonica, HARTMEYER (1911): Bromn. Tier-Reich, Bd. III, Suppl, p. 1340.

Pyura momus f. galei; MICHAEISEN (1927): Zool. Anz., Bd 71, pp. 194-195.

Cynthia complanata; HERDMAN (1882): Rep. Voy. Challenger, Vol. VI, Tunicata, pp. 145146, P1. XVII, figs. 1-9.

Microcosmus Draschii; HERDMAN (1899): Descriptive Catalogue of the Tunicata in the Australian Museum, pp. 20-23, P!. Cyn. III \& IV.

Halocynthia grandis; MrcHAEISEN (1905): Zool. Jahrb., Syst. Suppl., Vol. 8, pp. 85-91.

Pyura pallida f. grandis; HARTMEYER (1911): Bronn. Tier-Reich., Bd. III, Suppl., p. 1340.

Pyura momus f. grandis; HAstiNGS (1931): Great Barrier Reef Exped., Sci. Rep., Vol. IV, No. 3 , p. 72 .

Pyura pallida f japonica; HARTMEYER (1911): Bronn. Tier Reich., Bd. III, Suppi. p. 1340.

Cynthia papietensis; HERDMAN (1882): Rep. Voy. Challenger, Vo?. VI, Tunicata, pp. 143145, P1. XVII, figs. 10-16.

Pyura pallida f. papietonsis ; HARTMEYeR (1911): Bronn. Tier Reich., Bd. III, Suppl., p. 1340 .

Rhabdocynthia tenuis; HERDMAN (1891): Jnl. Linn. Soc. Zool., Vol. XXIII.

Pyura pallida f. tonuis; HARTMEXER (1911): Bronn. Tier-Reich., Bd. III, Suppl., p. 1340.

Forty-five $\mathrm{mm}$ long and $25 \mathrm{~mm}$ long individuals collected by Mr. S. WADA were at my disposal. Test pinkish to light red in the pres rved state, semitransparent, soft cartilaginous and $1-2 \mathrm{~mm}$ in thickness. The surface with irregular grooves and folds and adheres some foreign matters such as sand grains and shell fragments. Siphons distinct in the larger individual, while quite obscure in the smaller individual. Both apertures 4-lobed. Mantle pinkish and thin. Branchial sac with 9 folds on each side and with the following vessel-formula.

$45 \mathrm{~mm}$ long individual;
Left.
D. 13
(19) 5 (19) 5
(26)
(29) 5
(29) 5
(28) $5 \cdot(22)$
5 (14) 4 (3) 1 V. 

Right
D. 10
(16) 5
(25) 5
(28) 5
(29) 5
(30) 6
(27) 5
(26)
6 (14) 5 (4) $2 \mathrm{~V}$.

$25 \mathrm{~mm}$ long individual:
Left
D. 8 (18)
(22) 3
(25) 3
(22)
$\begin{array}{lllll}5 & (21) & 5 & (18) & 5\end{array}$
Right
D. 6
(17) 4
(19) 4
(24) 4
(24) 3 (22) 4
(4) $1 \mathrm{~V}$.
3 (12) 3 . (4) 1 V.
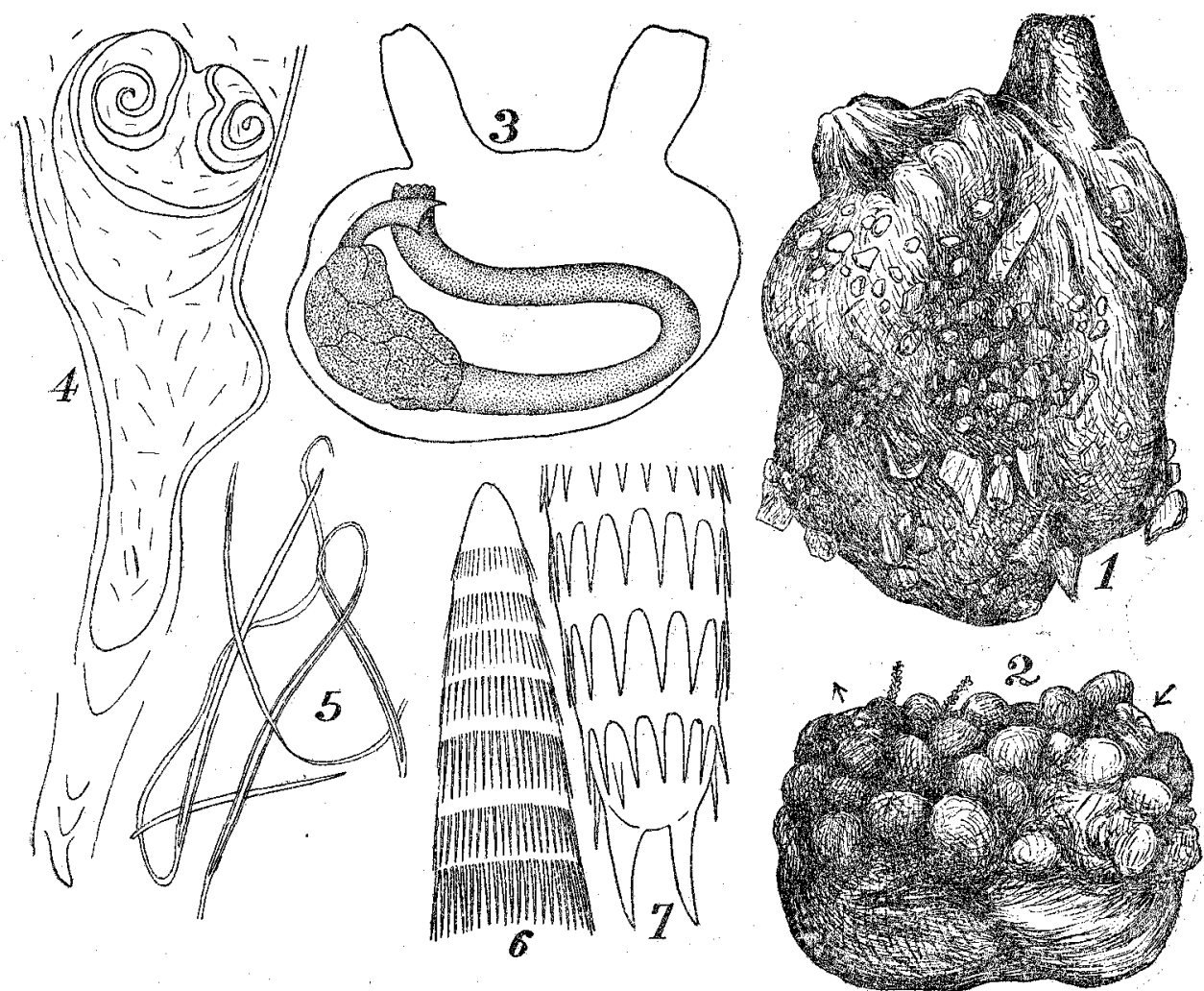

Fig .29. Herdmania momus (SAVIGNY). 1-4.5 mm long individual from right sida $2-25$ $\mathrm{mm}$ long individual from right side, 3-Right half from insite, 4-Dorsal tubercie $\times 12$, 5 -Spicules in sheaths $\times 28,6$-Acute tip of a spicule $\times 1200,7$-Blant tip of a spicule $\times 1200$.

About 7 thin vessels between thick ones. Parastigmatic vessels present. Four to five stigmata in a mesh. Tentacles 23 , excluding minute ones, in larger specimen; branches in 4 orders. Margin of anus lobated. Gonad not found in both specimens. 


\section{LITERATURE}

AldeR, J. \& HANCOCK, A. (1907): The Brtitish Tunicata, Vol. II. pp. 164, Figs. 86, Pls. 2150.

BerRII. N. J. (1932) : Ascidians of the Bermudas, Biol. Bull., Vol. 62, pp. 77-88, Figs. 1-5.

Bovien, P. (1921): Ascidiae from the A.ukland and Campbell Islands, Vid. Meddel. Dansk. naturh. Fōren., Bd. 73, pp. 33-47, Figs. 1-5, P1. 4.

BrewIN, B. I. $\{1950)$ : A.scidians from Otago Coastal Waters, Trans. Roy. Soc. New Zealand, Vol. 78, Pt. 1, pp. 54-63, Figs. 1-5.

(1950): Ascidians of New Zealand Part IV. Ascidians in the Vicinity of Christchurch, Trans. Roy. Soc. New Zealand, Vol. 78, Pt. 2-3, pp. 344-353, Figs. 1-5.

(1950): Ascidians of New Zealand Part V. Ascidians from the East Coast of Great

Barrier Island, Trans. Roy. Soc. New Zealand, Vol 78, Pt. 2-3, pp. 354-362, Figs. 1-7. (1950): The Ascidians of the Sub-antarctic Islands of New Zealand, Cape Expedition Series, Bull. No. 11, pp. 11, Figs. 1-3.

GotTSchaidT, R. (1898): Synascidien von Ternate, Abh. Senckenb. naturf. Ges., Bd. 24, pp. 641-660, Taf. $35-36$.

HARTMEYER, R. (1900): Monascidien von Ternate, Abh. Senckenb. naturf. Ges., Bd. 25, pp. 3-12, Taf. 1 .

(1900): Nachtrag zu Monascidien von Ternate, Abh. Senckenb. naturf. Ges., Bd. 25, pp. 235-242, Taf. X.

Figs. A-C. (1905): Ascidien von Mauritius, Zool, Jahrb. Syst. Suppl., Bd. 8 pp. $: 86-406$, Pl. 13,

(1906): Ein Beitrag zu Kentniss der japanischen Ascidienfauna, Zool. Anz., Bd. 31, pp. 1-30, Figs. 1-12.

(1909-1911): Ascidien in Bronn's Tier-Reich, Bd. 3, Suppl. pp. 1280-1773, 41 Pls.

(1911): Die Ascidien der deutschen Südpolar-Expedition, 1901-1903; Deutsch. Südpolar-Exped., Bd. 12, pp. 403-506, Taf. 45-57, Figs. 1-14.

(1912): Die Ascidien der deutschen Tiefsee-Expedition, Wiss. Ergeb. Deutsch. Tiefsee-Exped, Bd. 16, pp. 225-392, Taf. 37-44, Figs. e-10, 2 Maps.

(1919): Results of Dr. Mjöbergs Swedish Scientific Expeditions to Austral:a 191013. XXV Ascidien, Kungl. Sevensk. Vetenskapsakad. Handl. Bd. 60, No. 4, pp. 1-150, Figs. 1-25, 2 Pis.

HAST NGS, A. B. (1931) : Tunicata in Great Barrier Reef Exped., Sci. Rep., Vol. IV, No. 3, pp. $69-110$, Pls. I-III, Figs. 1-17.

HERDMAN, W. A. (1882): Report on the Tunicata collected during the Voyage of H, M.S. Challenger during the years 1873-1876. Part 1. Ascidiae Simplices, Rep. Voy. Challenger, Zool. Vol. VI, Part 17 Tunicata, pp. 1-296, Pls. 1-37.

- $\{1886\}$ : Report on the Tunicata collected during the Voyage of H.M.S. Challenger during the years 1873-1876. Part II. Ascidiae Compositae, Rep. Voy. Challenger, Zool. Vol. XIV Tunicata, pp. 1-432, Pls. 1-49.

(1891): A revised Classification of the Tunicata, Jnl. Linn. Soc. Zool., Vol. XXIII, pp. $558-652$.

21899): Descriptive Catalogue of the Tunicata in the Australian Museum, Liverpool, xviii +139 pp., 45 Pls.

- (1906): Report on the Tunicata collected by Prof. Herdman at Ceylon in 1902, Rep. Ceylon Pearl Oyster Fish., Pt. 5, Suppl. Rep No. 39, pp. 295-348, Pls. 1-9.

Hưs, J. (1937): Ascidiaceae in Kükenthal \& Krumdach: Handb. d. Zool., Bd. 5 Tuuicata, pp. 545-692, Figs. 454-581. 
Kestevens, H. L. (1909): Studies on Tunicata. No. 1, Proc. Linn. Soc. New South Wales, Vol. 34, pp. 27o-295, Pls. 25-27.

Michaessen, W. (1904): Die stolidobranchiaten Ascidien der deutschen Tiefsee-Expedition, Wiss. Ergebn. Deutsche. Tiefsee Exped., Bd. 7, pp. 181-260, Pls. 10-13.

(1905): Revision von Hellers Ascidientypen aus dem Museum Godeffroy, Zool. Jahrb., Syst. Suppl., Bd. 8, pp. 71-120, Pls. 4.

(1921): Ascidien vom westlichen Indischen Ozean aus dem Reichsmuseum zu Stockholm, Ark. f. Zool., Bd. 13, No. 23, pp. 1-25, Taf. 1.

(1922): Papers from Dr. Th. Mortensen's Pacific Expedition 1914-16. XI. Ascidiae

Ptychobranchiae und Diktyobranchiae von Neuseeland und den Chatham Inseln, Vidensk. Medd, fra Dansk naturh. Foren., Bd. 73, pp. 359-498, Figs. 35.

- (1924): Papers from Dr. Th. Mortensen's Pacific Expedition 1914-16. XXII Ascidiae Krikobranchiae von Neuseeland, den Chatham und den Aukland Inseln, Vidensk. Mèdd. fra Dansk naturh. Foren., Bd. 77, pp. 263-434, Figs. 30.

pp. $193-203$

11927): Einige neue westaustrallische Ptychobranchiate Ascidien, Zool. Anz, Bd. 71,

OKA, A. (1906): Notizen äber japanische Ascidien I, Annot. Zool. Japon., Vol. VI, Pt. 1, pp. $37-52$.

(1915): Report upon the Tunicata in the Collection of the Indian Museum, Mem. Indian Mus, Vol. VI, pp. 1-33, Pls. I-V.

1935 : Report of the Biological Survey of Mutsu Bay. 28 Ascidiae Simplices, Sci. Rep. Tôhoku Imp Univ. 4h Ser., Vol. X, pp. 427-463, Figs. 1-35.

PERAS, J. M. (1949): Contribution a létudes des Ascidies de la côte occidentale dAfrique, Bull. l'Inst. franc. d'Afrique noire, Tom. XI, pp. 159-207, Figs. 1-27.

Pizon, A. (1908): Ascidies d'Amboine, Rev. Suiss Zool., Tom. 16, pp. 195-240, Pls. 9-14.

RITTER, W. E. \& FORSYTH, R. A. (1917): Ascidians of the littoral zone of southern California, Univ. California Publ. Zool., Vol. 16, pp. 439-512, Pls. 38-46.

SALFI, M. (1931): Gli Ascidiacei del Golfo di Napoli, Pubbl. Staz. Zool. Napoli, Vol, XI, Fasc. 3, pp. 293-360, Pls. VI-X, Figs. 49.

SlUITER, C. PH. (1885): Uebər einige einfache Ascidien von der Insel Billiton, Natuurk. Tijdschr. Ned. Ind., Vol. 45, pp. 160-232, Pis. 1-9.

(1885): Einfache Ascidien aus der Bai von Batavia, Natuurk. Tijdschr. Ned-Ind., Bd. 46 , pp 242-266, Pis. 1-3.

(1890) : Die Evertebraten aus der Sammlung des Kgl. naturw. Vereins in Nederl.

Ind. in Batavia. Zugleich eine Skizze der Fauna des Java Meeres mit Beschreibung der neuen Arten Ascidiae Simplices, Natuurk. Tijdschr. Ned.Ind., Bd. 50, pp. 329-348, Pls. 1 \& 2.

(1895: Tunicata in Semon Zoojogische Forschungsreisen in Australien, etc. Bd. 5,

Denkschr. med. naturwiss. Gesell. Jena, Bd. 2, pp. 163-186, Figs. 5, Pis. 8.

(1897): Tunicata von Südafrika Beitrüge zur Kenntniss der Fauna von Südafrika

II), Zool. Jahrb. Syst., Bd. 11.

(1900): Tunicaten aus dem Stillen Ozean, Ergebnisse einer Reise nach dem Pacific,

Zool. Jahrb., Syst., Bd. 13, pp. 1-35, Pis. 1-6.

(1904): Die Tunicaten der Siboga-Expedition. Pt. 1 Die sozialen und holosomen

Ascidien, Siboga Exped, Monogr. 56 a, pp. 1-126, Pls. 1-15.

(1909): Die Tunicaten der Siboga-Expedition. Pt. 2 Die Merosomen Ascidien,

Siboga-Exped:, Monogr. 55 b, pp. 1-112, Pls. 1-8, Figs. 1 \& 2.

(1914): Ascidien von den Aru-Inseln, Abhandl. Senckenberg. Naturforsch. Gesell.,

Bd. 35, Hft. 1, pp. 65-78, Pls. 5 \& 6.

(1919): Ueber einige alte und neue Ascidien aus dem Zoologischen Museum von

Amsterdam, Bijd. Dierk., Af. XXI, pp. 1-12, Pl. 1. 
TokiokA, T. \{1942): Ascidians found on the Mangrove Trees in Iwayama Bay, Palao, Palao Tropical Biol. Stat. Studies, Vol. II, No. 3, pp. 497-505, Pl. IV, Figs. 1 \& 2.

(1949): Contributions to the Japanese Ascidian Fauna I. Ascidians collected by Prof. Miyadi and Mr. Masui during the Bottom Survey 1939-40, Publ. Seto Mar. Biol. Lab., I (1), pp. 1-17, Pls. 1-7.

(1949;: Contributions to Japanese Ascidian Fauna II. Notes on some Ascidians collected chiefly along the coast of Kii Peninsula, Publ. Seto Mar. Biol. Lab., I (2), pp 3964, Pl. VIII, Figs. 1-16.

(1950): Ascidians from the Palao Islands. I, Publ. Seto Mar. Biol, Lab., I \{3), pp. 115-150, P.s. IX \& X, Figs. 1-23.

TRAustedT, M. P. A. 1885): Ascidiae simplices fra det Stille Hav, Vidensk. Meddel. fra naturh. Foren, ann. 1884, pp. 1-60, Pls. 1-4.

TRAustedt, M. P. A. \& WeltNer, W. (1894): Bericht ïber die von Herrn. Dr. Sander gesammelten Tunicaten, Arch. Naturgesch., Bd. 60, Pt. 1, pp. 10-14, Pl. 2.

VAN NAME, W G. (1902; : The Ascidians of the Bermuda Isiands, Trans. Connecticut Acad. Sci., Vol. 11, pp. 325-412, Pls. 46-64.

(1918): Ascidians from the Philippine and Adjacent Waters, Smithson. Inst. U. S., Na1. Mus., Bull. 100, Vol. 1, Pt. 2, pp. 49-111, Pls. 23-33, Figs. 115. (1921): Ascidians of the West Indian Region and Southeastern United States, Bull.

American Mus. Nat. Hist., Vol. 44, pp. 283-494, Figs. 1-159.

(1924): Ascidians from Curaçao, Bijd. Dierk, Af. XXIII, pp. 23-32, Figs. 1-7.

(1945): The North and South American Ascidians, Bull. American Mus. Nat. Hist.,

Vol. 84, pp. 1-476, Pls. 1-31, Figs. 327. 